\title{
Interannual variability in global biomass burning emissions from 1997 to 2004
}

\author{
G. R. van der Werf $^{1}$, J. T. Randerson ${ }^{2}$, L. Giglio ${ }^{3}$, G. J. Collatz ${ }^{4}$, P. S. Kasibhatla ${ }^{5}$, and A. F. Arellano, Jr. , $^{\text {* }}$ \\ ${ }^{1}$ Department of Hydrology and Geo-Environmental Sciences, Faculty of Earth and Life Sciences, Vrije Universiteit, \\ Amsterdam, Netherlands \\ ${ }^{2}$ Department of Earth System Science, University of California, Irvine, California, USA \\ ${ }^{3}$ Science Systems and Applications, Inc., NASA Goddard Space Flight Center, Greenbelt, Maryland, USA \\ ${ }^{4}$ NASA Goddard Space Flight Center, Greenbelt, Maryland, USA \\ ${ }^{5}$ Nicholas School of the Environment and Earth Sciences, Duke University, Durham, North Carolina, USA \\ *now at: National Center for Atmospheric Research, Boulder, Colorado, USA
}

Received: 22 December 2005 - Published in Atmos. Chem. Phys. Discuss.: 18 April 2006

Revised: 14 July 2006 - Accepted: 28 July 2006 - Published: 21 August 2006

\begin{abstract}
Biomass burning represents an important source of atmospheric aerosols and greenhouse gases, yet little is known about its interannual variability or the underlying mechanisms regulating this variability at continental to global scales. Here we investigated fire emissions during the 8 year period from 1997 to 2004 using satellite data and the CASA biogeochemical model. Burned area from 20012004 was derived using newly available active fire and 500 $\mathrm{m}$. burned area datasets from MODIS following the approach described by Giglio et al. (2006). ATSR and VIRS satellite data were used to extend the burned area time series back in time through 1997. In our analysis we estimated fuel loads, including organic soil layer and peatland fuels, and the net flux from terrestrial ecosystems as the balance between net primary production (NPP), heterotrophic respiration $\left(R_{h}\right)$, and biomass burning, using time varying inputs of precipitation (PPT), temperature, solar radiation, and satellite-derived fractional absorbed photosynthetically active radiation (fAPAR). For the 1997-2004 period, we found that on average approximately $58 \mathrm{PgC} \mathrm{Cear}^{-1}$ was fixed by plants as NPP, and approximately $95 \%$ of this was returned back to the atmosphere via $R_{h}$. Another $4 \%$, or $2.5 \mathrm{Pg} \mathrm{C}_{\text {year }}{ }^{-1}$ was emitted by biomass burning; the remainder consisted of losses from fuel wood collection and subsequent burning. At a global scale, burned area and total fire emissions were largely decoupled from year to year. Total carbon emissions tracked burning in forested areas (including deforestation fires in the tropics), whereas burned area was largely controlled by savanna fires that responded to different environmental and human factors. Biomass burning emissions showed large interannual variability with a range of more than $1 \mathrm{PgC}$ year $^{-1}$,
\end{abstract}

Correspondence to: G. R. van der Werf

(guido.van.der.werf@falw.vu.nl) with a maximum in 1998 (3.2 $\left.\mathrm{Pg} \mathrm{C}_{\text {year }}{ }^{-1}\right)$ and a minimum in $2000\left(2.0 \mathrm{Pg} \mathrm{C}_{\text {year }}{ }^{-1}\right)$.

\section{Introduction}

The link between El Niño - Southern Oscillation (ENSO) and the $\mathrm{CO}_{2}$ growth rate variability is well established (Bacastow, 1976; Keeling et al., 1995) and provides a test case scenario for the effects of future climate change under warm and dry conditions. During El Niño, drought in equatorial Asia and Central and South America simultaneously influences fire activity, net primary production (NPP) and heterotrophic respiration $\left(R_{h}\right)$ in terrestrial ecosystems in a way that increases the growth rate of atmospheric $\mathrm{CO}_{2}$. Although drought is known to trigger increases in fire emissions, its effect on the balance between NPP and $R_{h}$ remains uncertain. In temperate ecosystems, for example, warm and dry conditions increased rates of carbon uptake in a hardwood forest (Goulden et al., 1996), whereas a strong drought in Europe during the summer of 2003 led to carbon loss from multiple ecosystems (Ciais et al., 2005). In boreal regions, increased temperature may trigger increased soil thaw and a loss of soil carbon through increased $R_{h}$ (Oechel et al., 1993; Goulden et al., 1998). In tropical regions, deep roots may enable trees to maintain high productivity during the dry season, whereas the metabolic activity of surface soil microbes are simultaneously inhibited during these periods, lowering $R_{h}$ and leading to a net carbon sink (Saleska et al., 2003). Longer-term time series of flux measurements from tropical ecosystems are sparse and limit our ability to assess the effect of drought on interannual to decadal timescales.

Published by Copernicus GmbH on behalf of the European Geosciences Union. 
Several recent studies provide evidence that fires account for a substantial fraction of the variability in the $\mathrm{CO}_{2}$ growth rate (Langenfelds et al., 2002; Schimel and Baker, 2002; van der Werf et al., 2004), suggesting that variations in NPP and $R_{h}$ are more closely coupled than previously thought. Observations from Indonesia show that fires in drained peatlands were a dominant source of emissions from this region during the 1997-1998 El Niño (Page et al., 2002). Interannual variability (IAV) in boreal fire activity is also large (Amiro et al., 2001; Sukhinin et al., 2004) and may be linked with the Arctic Oscillation (Balzter et al., 2005), ENSO (Hess et al., 2001), temperature anomalies (Balzter et al., 2005; Flannigan et al., 2005), and with human activity (Mollicone et al., 2006). At a global scale, two studies have assessed interannual variability in biomass burning emissions on a global scale using satellite data (Duncan et al., 2003; van der Werf et al., 2004). Biomass burning estimates are uncertain but are becoming better constrained, primarily by new satellite information on burned area, improved biogeochemical models used for estimating fuel loads, and atmospheric tracer inverse modeling studies. Assuming that IAV in ocean - atmosphere exchange is relatively small as compared with that associated with the terrestrial biosphere (Lee et al., 1998; Battle et al., 2000; Bousquet et al., 2000), reliable estimates of global biomass burning emissions may help to further constrain the climate sensitivity of processes within the terrestrial biosphere.

Fire emissions are commonly calculated as the product of burned area, fuel loads, and combustion completeness, integrated over the time and space scale of interest. Burned area is usually considered to be the most uncertain parameter in emission estimates, and burned area estimates on a global scale have only recently become available. Both the GBA2000 (Grégoire et al., 2002) and GLOBSCAR (Simon et al., 2004) efforts have yielded burned area estimates for the year 2000. The algorithms used in both projects were recently combined to estimate burned area over a longer time series in the GLOBCARBON initiative (Plummer et al., 2006). Other approaches to estimate burned area on large scales rely on the detection of active fires (fire counts) and relationships between these fire counts and burned area (van der Werf et al., 2003; Giglio et al., 2006). More detailed information on burned area is available for specific regions, and provides a basis for validating burned area algorithms developed at a global scale. Sukhinin et al. (2004) for example, estimated burned area for the 1995-2002 period for Russia using AVHRR data, and estimates of Canadian burned area from the Canadian Forest Service provide the longest time series of burned area available (Stocks et al., 2002). Fuel loads are the next most uncertain parameter required for estimates of fire emissions. Historically, biome-averaged values were used, but more recently satellite imagery has been used to represent heterogeneity within biomes (e.g., Scholes et al., 1996; Barbosa et al., 1999). Currently, most studies employ biogeochemical models to more accurately estimate fuel loads. This approach allows for a more direct comparison of aboveground biomass levels estimated by the model with spatially explicit maps generated from remote sensing and field based studies (e.g., Houghton et al., 2001; Saatchi et al., 2001; Le Toan et al., 2004). Use of biogeochemical models also enables the incorporation of process-level information on herbivory and fuel wood collection that are important controllers of fuel levels and will likely respond to global change processes and growing populations over the next several decades. The Lund-Potsdam-Jena (LPJ) model has been used in several studies to estimate emissions, including estimating contemporary levels (Hoelzemann et al., 2004) and emissions during the Last Glacial Maximum (Thonicke et al., 2005). We previously implemented a fire module in the Carnegie-Ames-Stanford-Approach (CASA) model to estimate contemporary patterns of tropical fire emissions (van der Werf et al., 2003), global variations in fire emissions over an ENSO cycle (van der Werf et al., 2004), and the effect of variable burning in $\mathrm{C}_{3}$ and $\mathrm{C}_{4}$ ecosystems on atmospheric $\delta^{13} \mathrm{CO}_{2}$ (Randerson et al., 2005). Regional-scale models have been employed to improve emissions predictions from boreal regions, including the combustion of belowground fuels (Kasischke et al., 2005). Recent work indicates that the burning of belowground fuels may also be an important source of emissions in tropical regions (Page et al., 2002). Vast amounts of peat have been drained in Indonesia and are vulnerable to fire during droughts, which happened during the 1997-1998 El Niño, releasing large quantities of carbon to the atmosphere (Page et al., 2002).

Only a fraction of the available fuel load is consumed during a fire event, and this fraction is represented within models by combustion completeness (CC). CC has been measured in the field for various biome and fuel types (e.g., Carvalho et al., 1995; Shea et al., 1996; Hoffa et al., 1999), and varies over the course of the fire season with more complete combustion at the end when fuels have had more time to dry out, as shown by Hoffa et al. (1999) for savanna ecosystems. In general, fine and dry fuels burn more completely than coarse and wet fuels, although a paucity of data makes it challenging to quantitatively link CC with climate in global models. Although significant effort has been made to improve burned area and fuel estimates, uncertainties are still large and difficult to quantify, particularly in tropical forest biomes. Eliminating the need for explicit knowledge of burned area, fuel loads, and CC, Wooster (2002), Roberts et al. (2005), and Ichoku et al. (2005) have shown for selected regions that satellite-derived fire radiative energy can be used to directly estimate emissions, potentially providing an independent quantification of emissions.

New studies employing inverse modeling techniques combined with atmospheric measurements of trace gases allow for an independent estimate of biomass burning emissions, and progress has been made in identifying deficiencies of current bottom-up estimates. To better constrain biomass burning estimates, comparisons with measurements 
of atmospheric $\mathrm{CO}$ have proven especially useful since biomass burning is a major source of $\mathrm{CO}$ and is responsible for almost all of its interannual variability (Novelli et al., 2003; van der Werf et al., 2004). Arellano et al. (2004) used data from the Measurements Of Pollution In The Troposphere (MOPITT) sensor to demonstrate that inventories underestimated fossil fuel emissions from Asia, and identified several areas where our previous estimates of biomass burning emissions were inadequate. In a similar study that also examined seasonal patterns, Pétron et al. (2004) demonstrated that MOPITT observations provided additional constraints on the seasonal timing of fire emissions in the Southern Hemisphere, especially in southern Africa.

Here we estimated biomass burning emissions on a global scale over the 1997-2004 period. We used the satellitedriven CASA biogeochemical model (Potter et al., 1993; Field et al., 1995; Randerson et al., 1996) that was previously modified to account for fires (van der Werf et al., 2003), in combination with a burned area time series derived from the MODIS sensors (Giglio et al., 2006). We extended the burned area time series back in time before MODIS using data on fire activity from Arino et al. (1999) and Giglio et al. (2003b). Our overall goal was to improve global biomass burning estimates, with specific objectives to better represent fuel loads in the boreal ecosystems and in global wetlands by modeling the burning of organic soil layers and peat, to improve the seasonality of emissions in regions where inverse studies indicated that forward modeling estimates may inadequately represent regional dynamics, and to analyze the relation between burned area and emissions on a global scale.

\section{Methods}

\subsection{Burned area for the MODIS period (2001-2004)}

For our analysis, we used the burned area data set developed by Giglio et al. (2006). Burned area was mapped at $500 \times 500 \mathrm{~m}$. spatial resolution within 52 globally-distributed MODIS tiles, with each tile covering an area of approximately $10^{\circ} \times 10^{\circ}$, for different time periods between 2001 and 2004 (Giglio et al., 2006 ${ }^{1}$ ). MODIS fire counts (Giglio et al., 2003a) were then calibrated to the 500-m burned area within $1^{\circ} \times 1^{\circ}$ grid cells on a monthly basis, taking advantage of additional information about fire cluster size, fractional woody cover, herbaceous cover, or bare ground (Vegetation Continuous Fields, VCF; Hansen et al., 2003), and fire persistence. A unique regression tree was produced for each region shown in Fig. 1. The coefficients derived from the regression trees were then used with the MODIS fire count time series to generate global monthly burned area estimates from January 2001 through December 2004. The selection of regions shown in Fig. 1 and Table 1 was based on similar-

\footnotetext{
${ }^{1}$ Giglio, L., et al.: in preparation, 2006.
}

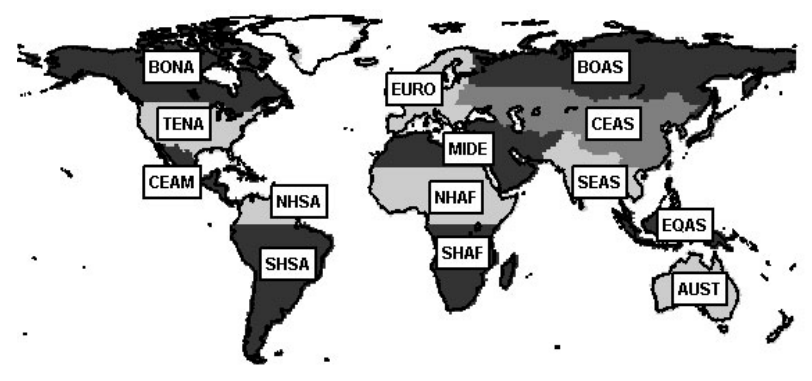

Fig. 1. Map of the 14 regions used in this study. Abbreviations are explained in Table 1.

ities in fire behaviour and also on suitability for use as basis regions in atmospheric tracer inversion studies.

\subsection{Burned area prior to the MODIS period}

The Terra satellite that carried the first MODIS sensor was launched in December of 1999, but here we only used observations starting in January 2001 because of inconsistent calibration during the first year of operation. The 1997-2000 period included the strongest El Niño of the century associated with high fire emissions so we were motivated to extend our analysis back to include this period. To extend the time series back in time to January 1997, we used fire counts from the Tropical Rainfall Measuring Mission (TRMM) - Visible and Infrared Scanner (VIRS) and European Remote Sensing Satellites (ERS) Along Track Scanning Radiometer (ATSR) sensors. VIRS observations are available for the TRMM footprint $\left(38^{\circ} \mathrm{N}-38^{\circ} \mathrm{S}\right)$, starting in January 1998 (Giglio et al., 2003b). ATSR observations are available globally, starting in July 1996 (Arino et al., 1999).

A comparison of the MODIS burned area time series with VIRS and ATSR observations over the 2001-2003 period revealed two important differences between the datasets. The first was a difference in seasonality. In Southern Hemisphere tropical ecosystems, and particularly in southern Africa, VIRS fire counts peaked about two months earlier than ATSR and MODIS. Second, ATSR fire counts at the end of 2001 were anomalously low in northern Africa as compared to both VIRS and MODIS observations. Because of these differences, in Africa we chose to use VIRS to set the IAV for the 1998-2000 period (and ATSR for 1997), while maintaining the seasonality as averaged over the 2001-2004 period from MODIS. For all other regions we used ATSR fire counts to set both the seasonal cycle and IAV. The procedure used to convert VIRS or ATSR fire counts to burned area was based on an analysis of the 2001-2003 MODIS overlap period. For each grid cell the 2001-2003 cumulative burned area for the three years derived from MODIS was divided by the cumulative VIRS/ATSR fire counts. The ratio represents the burned area per VIRS/ATSR fire count and was used to estimate 
Table 1. Regions used within this study. Abbreviations refer to those used in Fig. 1.

\begin{tabular}{|c|c|c|}
\hline Abbreviation & Short Name & Comments \\
\hline BONA & Boreal North America & Alaska and Canada. \\
\hline TENA & Temperate North America & Conterminous United States. \\
\hline CEAM & Central America & Mexico and Central America. \\
\hline NHSA & $\begin{array}{l}\text { Northern Hemisphere } \\
\text { South America }\end{array}$ & Division with SHSA is at the equator \\
\hline SHSA & $\begin{array}{l}\text { Southern Hemisphere } \\
\text { South America }\end{array}$ & Division with NHSA is at the equator \\
\hline EURO & Europe & $\begin{array}{l}\text { Includes the Baltic States but excluding } \\
\text { Belarus and the Ukraine. }\end{array}$ \\
\hline MIDE & Middle East & $\begin{array}{l}\text { Africa north of the tropic of cancer, and } \\
\text { the Middle East including Afghanistan. }\end{array}$ \\
\hline NHAF & $\begin{array}{l}\text { Northern Hemisphere } \\
\text { Africa }\end{array}$ & $\begin{array}{l}\text { Africa between the tropic of Cancer and } \\
\text { the Equator. }\end{array}$ \\
\hline SHAF & $\begin{array}{l}\text { Southern Hemisphere } \\
\text { Africa }\end{array}$ & \\
\hline BOAS & Boreal Asia & $\begin{array}{l}\text { Russia, excluding the area south of } 55^{\circ} \mathrm{N} \\
\text { between the Ukraine and Kazakhstan. }\end{array}$ \\
\hline CEAS & Central Asia & $\begin{array}{l}\text { Mongolia, China, Japan, and the former } \\
\text { USSR except Russia. }\end{array}$ \\
\hline SEAS & Southeast Asia & $\begin{array}{l}\text { Asia east of Afghanistan and south of } \\
\text { China (including the Philippines). }\end{array}$ \\
\hline EQAS & Equatorial Asia & Malaysia, Indonesia, and Papua New Guinea. \\
\hline AUST & Australia & Includes New Zealand. \\
\hline
\end{tabular}

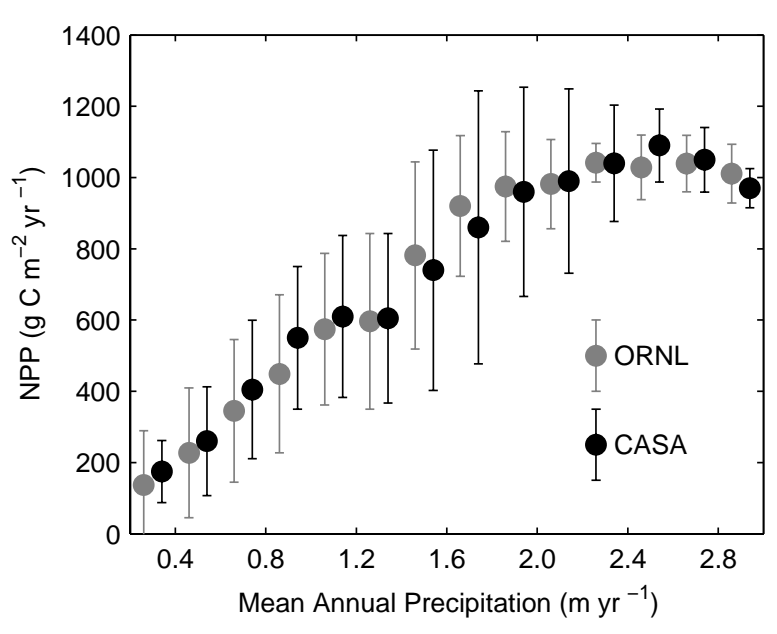

Fig. 2. Comparison of net primary production (NPP) estimated from the CASA model (used here) and measurements from the Oak Ridge National Laboratory (ORNL) NPP database. Error bars indicate the standard deviation. Measurements and model estimates are aggregated into $200 \mathrm{~mm}_{\text {year }}{ }^{-1}$ bins of mean annual precipitation.

burned area from VIRS/ATSR fire counts before the MODIS era. In grid cells where no fire counts and burned area were observed in the MODIS era but fire counts were observed by
VIRS/ATSR before the MODIS era, the weighted ratio from neighbouring grid cells was used. Our approach to estimate burned area may introduce biases because of the use of different sensors at the beginning and end of the time series, and ideally we would like to use a temporally consistent satellitederived burned area time series. Other uncertainties in our approach are related to the ATSR algorithm which is based on detecting fires at night. It may therefore have limited success in detecting fires in high latitudes that burn around summer solstice, and may have a bias towards large fires that burn into the night (Kasischke et al., 2003). However, until high quality burned area data become available, we believe our approach may serve as an interim solution in the context of exploring interannual variations of biomass burning emissions.

\subsection{Fuel loads}

For each month and grid cell, fuel loads were calculated based on the fuel load of the previous month, input from NPP, and losses from $R_{h}$, fire, fuel wood collection, and herbivory. NPP was calculated using satellite-based measurements of the Normalized Difference Vegetation Index (NDVI) from the Advanced Very High Resolution Radiometer (AVHRR) data processed by the Global Inventory Modeling and Mapping Studies (GIMMS) lab, version "g" (Pinzón et al., 2005; Tucker et al., 2005). NDVI was converted to 
fraction absorbed photosynthetic active radiation (fAPAR, see below), and NPP was calculated following the approach described by Field et al. (1995):

$\mathrm{NPP}=\mathrm{fAPAR} \times \mathrm{PAR} \times \varepsilon_{(T, P)}$

where PAR is photosynthetically active radiation, and $\varepsilon$ is the maximum light use efficiency (LUE) that is downscaled when temperature $(T)$ or moisture $(P)$ conditions are not optimal. See Table 2 for a summary of the different data sources that we used to drive CASA. We converted NDVI to fAPAR using techniques developed by Los et al. (2000). Monthly PAR was derived by adding anomalies from release 2 of the National Centers for Environmental Prediction (NCEP) reanalysis data (Kanamitsu et al., 2002) to average monthly PAR derived from Bishop and Rossow (1991).

Interannually varying fAPAR was used to calculate NPP for grid cells receiving less than $1000 \mathrm{~mm} \mathrm{year}^{-1}$ of mean annual PPT (MAP). Otherwise the monthly mean for the study period was used. This was done because for higher MAP regions (more productive, higher NPP) IAV was relatively low and may not exceed uncertainties in the NDVI observations caused by residual signals from cloudiness and smoke. For all grid cells interannually varying PAR, $T$, and PPT were used to calculate monthly NPP. A comparison between CASA NPP and results from the Oak Ridge National Laboratory (ORNL) data base (Olson et al., 2001; Zheng et al., 2003) is shown in Fig. 2 as a function of MAP. At high PPT levels, CASA NPP levels off and may slightly decrease in a way that is consistent with observations. Mechanistically both nutrient limitation and light limitation have been proposed as limits on NPP in these mesic environments (Schuur, 2003), although with the version of CASA used in this study light limitation was solely responsible for the model trend.

In CASA, NPP was distributed to live biomass pools (leaves, fine roots, and stems). Stems had a fixed turnover time depending on biome type. Leaf and fine root senescence depended on the seasonality of satellite-derived Leaf Area Index (LAI), with the largest transfer to heterotrophic pools occurring when LAI declined (Randerson et al., 1996). Each litter and soil organic matter pool had a maximum decomposition rate constant assigned that was reached only when soil moisture and temperature levels were not limiting. The temperature sensitivity of $R_{h}$ was based on a $\mathrm{Q}_{10}$ value of 1.5. The moisture scalar was based on a simple bucket soil moisture scheme that was a function of monthly PPT, $T$, and soil parameters including soil texture and moisture holding capacity. $R_{h}$ was limited when soil moisture was low, but also saturated soils caused a decrease in $R_{h}$ rates (Potter et al., 1993).

For each grid cell, we separately calculated the carbon exchange of herbaceous and of woody vegetation. NPP was allocated evenly to fine roots and leaves for herbaceous vegetation, and evenly to fine roots, leaves, and stems for woody vegetation. The total grid cell carbon fluxes were then calculated from the proportional coverage of herbaceous and

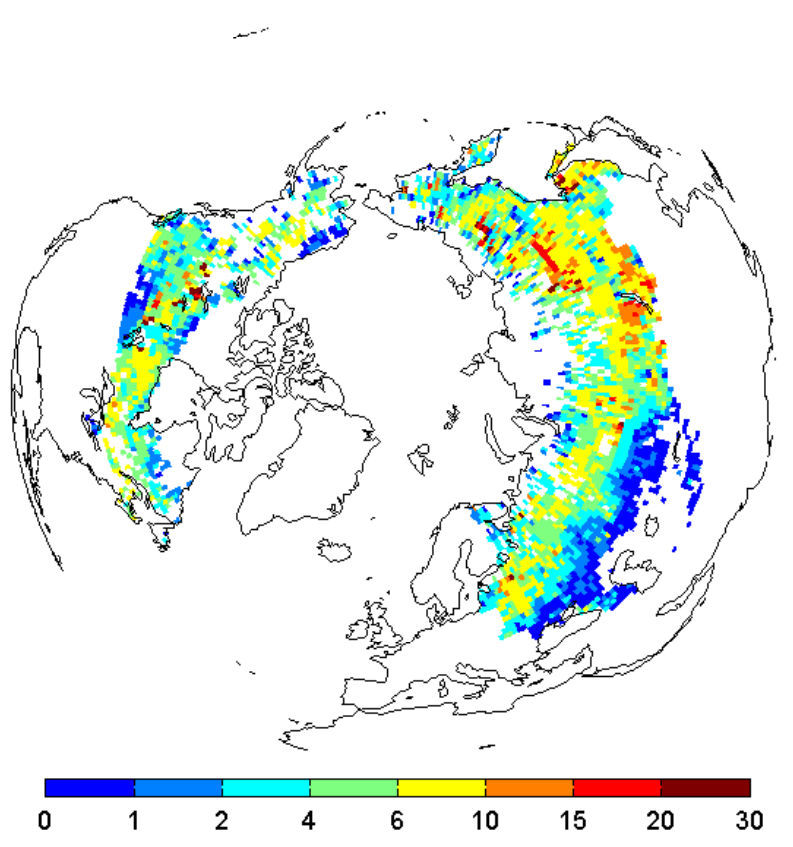

Fig. 3. Depth of burning $(\mathrm{cm})$ into the duff layer predicted by our model. Litter, coarse woody debris, and organic soil carbon consumed during fire were converted into burn depths using the soil carbon density profiles from Carrasco et al. (2006).

woody vegetation determined from the VCF. We estimated fuel wood collection and herbivory as in van der Werf et al. (2003). The main result of including these two processes was a decrease in fuel loads in savanna ecosystems, in better agreement with measured fuel loads (e.g., Shea et al., 1996; Hoffa et al., 1999). Within tropical forest ecosystems, aboveground biomass levels from the model were broadly consistent with published estimates. For example, published estimates of aboveground biomass levels for the Brazilian Amazon range from 39 to $93 \mathrm{PgC}$, with a mean of $70 \mathrm{PgC}$ and a standard deviation of $16 \mathrm{Pg} \mathrm{C}$ (Houghton et al., 2001). Here we estimated a total of $77 \mathrm{PgC}$ using CASA for this same region. In the future, satellite or aircraft based estimates of vegetation height may enable a further reduction in uncertainties in aboveground biomass estimates.

In the boreal region, a large fraction of fire emissions comes from the combustion of organic soils and peat. Recent research in Indonesia has also highlighted the importance of peat as fuel for combustion in tropical regions. The Indonesia case is unique in that peat deposits have been systematically drained and thus have become vulnerable to fire during periods of drought (Page et al., 2002). Modeling the combustion of the organic soil layer and peat is problematic because little information on depth of burning is available. Here we implemented a parameterization for boreal forest and tropical peatland soils that builds on the work of Ito and Penner (2004) and Kasischke et al. (2005). Within the CASA 
Table 2. Data sets used in this study.

\begin{tabular}{|c|c|c|c|c|c|}
\hline Variable & Role in CASA & Data product name & Source & $\begin{array}{l}\text { Product } \\
\text { Resolution }\end{array}$ & Reference \\
\hline Precipitation & $\mathrm{NPP}$ and $R_{h}$ & GPCP version 2 & $\begin{array}{l}\text { Multi-satellite } \\
\text { and rain gauges }\end{array}$ & $2.5^{\circ} \times 2.5^{\circ}$ & Adler et al. (2003) \\
\hline Temperature & $\mathrm{NPP}$ and $R_{h}$ & $\begin{array}{l}\text { Climatology: IIASA } \\
\text { IAV: GISTEMP }\end{array}$ & $\begin{array}{l}\text { Station data } \\
\text { Station data }\end{array}$ & $\begin{array}{l}0.5^{\circ} \times 0.5^{\circ} \\
2^{\circ} \times 2^{\circ}\end{array}$ & $\begin{array}{l}\text { Leemans and Cramer (1991) } \\
\text { Hansen et al. (1999) }\end{array}$ \\
\hline NDVI, scaled to fAPAR & NPP, leaf shedding & GIMMSg & AVHRR & $1^{\circ} \times 1^{\circ}$ & $\begin{array}{l}\text { Pinzón et al. (2005) } \\
\text { Tucker et al. (2005) }\end{array}$ \\
\hline Solar Radiation & NPP & $\begin{array}{l}\text { Climatology: ISCCP } \\
\text { IAV: NCEP R2 }\end{array}$ & & $\begin{array}{l}0.5^{\circ} \times 0.5^{\circ} \\
1^{\circ} \times 1^{\circ}\end{array}$ & $\begin{array}{l}\text { Bishop and Rossow (1991) } \\
\text { Kanamitsu et al. (2002) }\end{array}$ \\
\hline Vegetation continuous fields & $\begin{array}{l}\text { NPP allocation } \\
\text { Fired induced mortality rates }\end{array}$ & - & MODIS & $500 \times 500 \mathrm{~m}$ & Hansen et al. (2003) \\
\hline Burned area (2001 onwards) & Carbon losses from fire & - & MODIS & $500 \times 500 \mathrm{~m}$ & Giglio et al. (2006) \\
\hline Fire counts (2001 onwards) & Carbon losses from fire & - & MODIS & $1 \times 1 \mathrm{~km}$ & Giglio et al. (2003a) \\
\hline Fire counts (1997-2000) & Carbon losses from fire & $\begin{array}{l}\text { World Fire Atlas } \\
-\end{array}$ & $\begin{array}{l}\text { ATSR } \\
\text { VIRS }\end{array}$ & $\begin{array}{l}1 \times 1 \mathrm{~km} \\
0.5^{\circ} \times 0.5^{\circ}\end{array}$ & $\begin{array}{l}\text { Arino et al. (1999) } \\
\text { Giglio et al. (2003b) }\end{array}$ \\
\hline
\end{tabular}

framework, the spatial variability of carbon in the organic soil layer and peat is a function of local NPP and decomposition rates, with turnover times for different soil carbon pools scaled by monthly temperature and soil moisture. We adjusted the decomposition rate constants of the deeper, slowly decaying soil carbon pools (slow and passive pools) in the CASA framework so that the modelled estimates of total soil and surface carbon in boreal and peat regions matched measured values from Batjes (1999) to a depth of $30 \mathrm{~cm}$. The database compiled by Batjes (1999) is based on more than 4000 globally distributed soil profiles and has a $0.5^{\circ} \times 0.5^{\circ}$ spatial resolution. As a result, the largest adjustments to the decomposition rate constants were made in wetland areas, where anaerobic conditions lead to slow decay of carbon that was not previously taken into account in the model. We assumed that the deeper carbon in CASA (slow and passive pools) was only available as fuel in grid cells that were classified as wetlands (Matthews and Fung, 1987) which we assumed to represent peatlands. In other (boreal) grid cells, only carbon stored in upper soil layers (represented in CASA by the surface litter and active soil pools) was allowed to burn.

The maximum depth that the fires could burn into the organic soil layer or peat was constrained using literature values. In the tropical peat areas the depth was set to the maximum soil depth in CASA $(30 \mathrm{~cm}$.), but may burn even deeper according to Page et al. (2002). In the boreal regions the maximum depth was $10 \mathrm{~cm}$., corresponding to $1 / 3$ of the available soil carbon in CASA (based on the "moderate severity scenario" in Kasischke et al. (2005) and references therein). Not all of the organic soil layer and peat burns in a fire; often the late season fires burn deeper than early season fires because the soil is drier (Kasischke et al., 2005). Depth of burning was made a linear function of the soil moisture scalar; only when the soil was dry would the fires burn to the maximum depth as discussed above, corresponding to $1 / 3$ (boreal) and all (tropical) of the available carbon in the organic soil layer or peat in CASA. The moisture scalar simulates the first order effects of precipitation and evapotranspiration on soil moisture conditions, but may have limited applicability in regions where other conditions, e.g. permafrost, affect the moisture conditions of the soil. In tropical peat areas, fires were assumed to always consume a minimum of $50 \%$ of the soil carbon pools in CASA (representing human-induced drainage of peatlands; Page et al., 2002). The soil moisture scalar determined how much of the remaining $50 \%$ of the soil organic layers could burn.

We assumed that the carbon density did not change with depth. Even though several field studies have shown how the carbon density increases with depth, we believe that these studies are not yet sufficiently spatially representative to be included in a global model study. To test whether our assumption was valid, we used the carbon density profile from Carrasco et al. (2006) to see what the depth of burning would be when we combined our modelled organic soil layer consumption with this profile. The Carrasco et al. (2006) carbon density profile increases from approximately $0.015 \mathrm{~g} \mathrm{C} \mathrm{cm}^{-3}$ at the surface to approximately $0.020 \mathrm{~g} \mathrm{C} \mathrm{cm}^{-3}$ at $20 \mathrm{~cm}$, and approximately $0.040 \mathrm{~g} \mathrm{C} \mathrm{cm}^{-3}$ at a depth of $40 \mathrm{~cm}$. The depth of burning corresponding to losses from CASA organic soil layer and peat is shown in Fig. 3. Most of the forest fires burned to a depth of 4-10 cm. A few wetland areas had greater levels of fire severity, including fire complexes near Lake Baikal. Fires in grassland and agricultural ecosystems south of the boreal forest consumed only a few centimetres or less.

\subsection{Combustion completeness}

The ratio of fuel consumption to total available fuels is known as the combustion completeness (CC) or the 
combustion factor. Several generalities about $\mathrm{CC}$ have emerged from studies that have measured CC's in a wide range of vegetation types (e.g., Shea et al., 1996; Hoffa et al., 1999; Carvalho et al., 2001). First, CC of fine fuels is usually very high, up to 1 (complete combustion) for dry surface litter. Coarser fuels such as stems and woody debris, with a lower surface to volume ratio, burn less completely. In boreal regions foliage and twigs have a higher $\mathrm{CC}$ than living stems and boles in part because of their high water content. Even though the boles remain largely intact, boreal fires across North America and parts of Siberia frequently cause standreplacing mortality of the dominant conifer species. In contrast, in savannas fire-induced mortality of most large trees is quite low because they are protected by a thick bark and because ground fuels often do not produce flames high enough to reach the foliage (Gill, 1981). CC in tropical forests undergoing deforestation is more challenging to characterize. Carvalho et al. (2001) reported an increase in CC with an increase in cleared area in deforestation regions in the Brazilian state of Mato Grosso. Here, conversion is often highly mechanized and $\mathrm{CC}$ can approach unity over the course of a fire season as fuels including boles are piled together and ignited multiple times (D. C. Morton and R. S. DeFries, personal communication).

In CASA, we allowed CC to vary among fuel types (leaves, stems, and various litter pools), in contrast with earlier approaches where a single value was used for each biome. We also allowed CC to vary from month to month to simulate the effects of seasonal changes in fuel moisture content (Shea et al., 1996). We set minimum and maximum values for each fuel type (Table 3), and used moisture conditions to scale between these values. For live material (stems, foliage), CC was scaled linearly with the CASA NPP moisture scalar to take into account the effects of moisture content of the vegetation. $\mathrm{CC}$ of litter was scaled using the ratio of PPT over potential evaporation of the month of the fire and the previous month. To account for a longer memory of coarse fuels due to their greater volume to surface area ratio the relative weighing of the current and previous month was 6:4 for coarse woody debris and 9:1 for fine litter fuels.

To simulate higher $\mathrm{CC}$ due to repetitive burning in deforestation regions we increased the $\mathrm{CC}$ of stems and coarse litter in areas with high levels of fire persistence as identified using the remote sensing approach described by Giglio et al. (2006). In these grid cells, the CC value was multiplied with a factor equal to the fire persistence, with an upper threshold for CC of 1 .

\subsection{Emission factors}

Emission factors (EF) have been measured for multiple species in laboratories, ground based field studies, and from aircraft. EF's are usually defined as grams of trace gas emitted per kg of dry matter (DM) consumed during the fire. Andreae and Merlet (2001) reviewed most of these studies and
Table 3. Minimum and maximum combustion completeness (CC) for different fuel types.

\begin{tabular}{lll}
\hline Fuel Type & $\mathrm{CC}_{\min }$ & $\mathrm{CC}_{\max }$ \\
\hline Leaves & 0.8 & 1.0 \\
Stems & 0.2 & 0.3 \\
Fine leaf litter & 0.9 & 1.0 \\
Coarse woody debris & 0.5 & 0.6 \\
Organic soil layer and peat & 0.9 & 1.0 \\
\hline
\end{tabular}

compiled EF's for over 100 trace gas species. EF's were reported for different biomes and in general, the finer the fuel and thus the more efficient the fire, the higher the EF for $\mathrm{CO}_{2}$ and the lower the EF for most other (reduced) trace gases. The fraction of emitted carbon that is $\mathrm{CO}_{2}$ is usually referred to as combustion efficiency (CE). EF's are not constant within biomes as shown by the relatively large standard deviations reported by Andreae and Merlet (2001). One reason for variation within biomes may be the timing of fires; $\mathrm{CE}$ is usually lower in early season fires than in late season fires because fuels are drier later in the season. Korontzi et al. (2003), for example, showed how the EF for CO decreased from 100 to $40 \mathrm{~g} \mathrm{CO} / \mathrm{kg} \mathrm{DM}$ in the first 6 weeks of a grassland fire season, while the $\mathrm{CO}_{2} \mathrm{EF}$ increased from 1640 to $1770 \mathrm{~g} \mathrm{CO}_{2} / \mathrm{kg} \mathrm{DM}$ during the same period, indicating an increase in CE as the dry season progressed. On the other hand, woody vegetation may not combust until the end of the dry season, potentially decreasing the seasonal trend in EF. Because of this and because of limited information on the seasonal dependence of EF in other biomes, we have used the average values of Andreae and Merlet (2001) and Andreae (personal communication) in combination with the MODIS vegetation cover map (MOD12C1 with the IGBP land cover classification, available online at http://edcdaac.usgs.gov/modis/mod12c1v4.asp).

Andreae and Merlet (2001) report EF's for tropical forest, extratropical forest, and savanna and grassland. All grid cells in class 2 (evergreen broadleaf forest) were assigned the EF for tropical forest, all grid cells in classes 1, 3, 4, and 5 (evergreen needleleaf forest, deciduous needleleaf forest, deciduous broadleaf forest, and mixed forest, respectively) were assigned the EF for extratropical forest, and all other grid cells were assigned the EF for savanna and grassland. The higher EF for reduced carbon species in forests compared to savannas is linked with an increased fraction of coarse fuels that burn in the smouldering phase (Andreae and Merlet, 2001). In equatorial Asia, there were several savanna grid cells that had peat burning, because the Matthews and Fung (1987) maps indicated that these grid cells contained wetlands. For the combustion of the peat in these grid cells, we used the EF from tropical forest instead of savanna to account for the lower CE. Most EF's are reported for DM, we used a dry 
Table 4. 1997-2004 average NPP, fuel loads, fire return time (FRT), and combustion completeness (CC) for different regions.

\begin{tabular}{|c|c|c|c|c|c|c|c|c|c|c|c|}
\hline \multirow[t]{2}{*}{ Region } & \multirow{2}{*}{$\begin{array}{c}\mathrm{NPP} \\
\left(\mathrm{g} \mathrm{C} \mathrm{m}^{-2} \mathrm{yr}^{-1}\right)\end{array}$} & \multicolumn{3}{|c|}{ Fuel loads $\left(\mathrm{g} \mathrm{C} \mathrm{m}^{-2}\right)^{1,2}$} & \multirow[t]{2}{*}{ FRT (yr) } & \multicolumn{3}{|c|}{$\mathrm{CC}(-)^{3}$} & \multirow{2}{*}{$\begin{array}{c}\text { Total area } \\
\left(\times 10^{6} \mathrm{~km}^{2}\right)^{4}\end{array}$} & \multirow{2}{*}{$\begin{array}{c}\text { Emissions } \\
\left(\mathrm{g} \mathrm{C} \mathrm{m}^{-2} \mathrm{yr}^{-1}\right)\end{array}$} & \multirow{2}{*}{$\begin{array}{c}\text { Emissions/ } \\
\text { total losses }(\%)^{5}\end{array}$} \\
\hline & & Biomass & Litter & All & & Biomass & Litter & All & & & \\
\hline BONA & 266 & 1864 & 1641 & 3505 & 473 & 0.26 & 0.88 & 0.55 & 10.9 & 1918 & 1.5 \\
\hline TENA & 488 & 1296 & 941 & 2237 & 513 & 0.25 & 0.79 & 0.48 & 7.8 & 1070 & 0.4 \\
\hline CEAM & 573 & 1697 & 1742 & 3439 & 92 & 0.35 & 0.84 & 0.60 & 2.8 & 2062 & 3.8 \\
\hline NHSA & 938 & 1051 & 773 & 1824 & 79 & 0.43 & 0.83 & 0.60 & 3.0 & 1088 & 1.5 \\
\hline SHSA & 884 & 2143 & 1398 & 3541 & 117 & 0.48 & 0.86 & 0.63 & 14.9 & 2240 & 2.1 \\
\hline EURO & 438 & 206 & 638 & 843 & 241 & 0.47 & 0.81 & 0.73 & 5.3 & 612 & 0.6 \\
\hline MIDE & 46 & 42 & 194 & 235 & 4183 & 0.90 & 0.95 & 0.94 & 12.1 & 222 & 0.1 \\
\hline NHAF & 417 & 296 & 409 & 705 & 10 & 0.40 & 0.79 & 0.63 & 14.7 & 441 & 9.9 \\
\hline SHAF & 699 & 568 & 731 & 1299 & 13 & 0.32 & 0.75 & 0.56 & 9.8 & 734 & 8.1 \\
\hline BOAS & 327 & 1745 & 1753 & 3499 & 158 & 0.24 & 0.88 & 0.56 & 15.2 & 1959 & 3.7 \\
\hline CEAS & 256 & 93 & 247 & 341 & 106 & 0.58 & 0.91 & 0.82 & 18.1 & 278 & 1.0 \\
\hline SEAS & 471 & 1190 & 1120 & 2311 & 51 & 0.29 & 0.77 & 0.52 & 6.7 & 1209 & 4.9 \\
\hline EQAS & 847 & 3306 & 6593 & 9898 & 79 & 0.44 & 0.92 & 0.76 & 2.7 & 7542 & 10.1 \\
\hline AUST & 329 & 104 & 252 & 356 & 16 & 0.57 & 0.88 & 0.79 & 8.1 & 280 & 5.3 \\
\hline
\end{tabular}

${ }^{1}$ Fuel loads were weighted by burned area and separated into biomass fuel (which included all live herbaceous and woody biomass available for fire) and litter fuel (aboveground litter, coarse woody debris, belowground litter in boreal regions, and belowground peat in wetland regions).

${ }^{2}$ The fraction of woody biomass that was available for fire depended on the mortality scalar, as in van der Werf et al. (2003).

${ }^{3} \mathrm{CC}$ was weighted by burned area and by fuel loads and separated into biomass CC and litter CC similar to the fuel loads separation.

${ }^{4}$ Total surface area of the region.

${ }^{5}$ Total losses included emissions (both from vegetation fires and biofuel burning) and $R_{h}$.
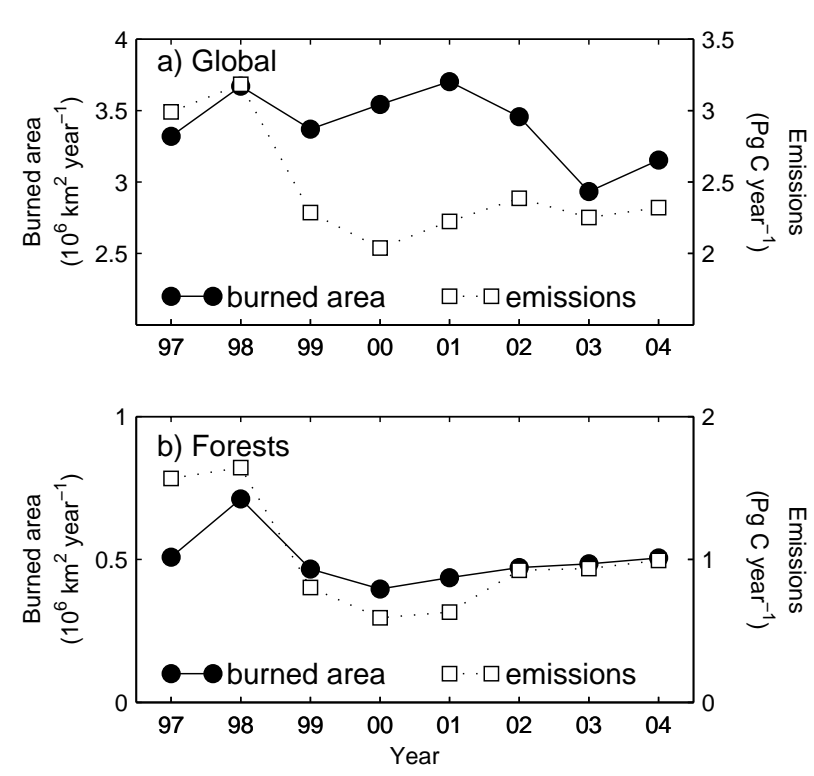

Fig. 4. Annual area burned and emissions for the globe (a) and for forested areas (b).

matter carbon content of $45 \%$ to convert carbon emissions to DM burned.

\section{Results and discussion}

\subsection{Global overview}

At a global scale, burned area and fire emissions were mostly decoupled over the 1997-2004 period (Fig. 4a). This was because most of the burned area occurred within savanna ecosystems that had relatively low fuel loads and emissions. Burned area within forest biomes accounted for less than $20 \%$ of global burned area averaged over the 1997-2004 period. Nevertheless, burning in forests was highly variable from year to year and this variability, coupled with high fuel loads, meant that forests contributed to most of the variability in emissions (Fig. 4b). An exception occurred in 1997, when burned area in forests was average but global emissions were high from fires in regions with tropical peatlands that have even higher fuel loads than forests (Table 4).

On average, emissions per unit burned area for the 20012004 period were $2.22 \mathrm{~kg} \mathrm{C} \mathrm{m}^{-2}$ year $^{-1}$ in forest grid cells and $0.52 \mathrm{~kg} \mathrm{C} \mathrm{m}^{-2}$ year $^{-1}$ in herbaceous grid cells (Fig. 5a, Table 4). Average emissions per fire count varied somewhat less between forest $\left(2.71 \times 10^{6} \mathrm{kgC}\right.$ fire count $^{-1}$ year $\left.^{-1}\right)$ and herbaceous $\left(0.90 \times 10^{6} \mathrm{~kg} \mathrm{C}\right.$ fire count ${ }^{-1}$ year $\left.^{-1}\right)$ biomes (Fig. 5b), suggesting that fire counts may partly integrate the combined effects of burned area and fuel loads. There was still considerable variability in the amount of emissions per fire count across different regions, however, indicating that the relationship between fire counts and emission is not uniform. 

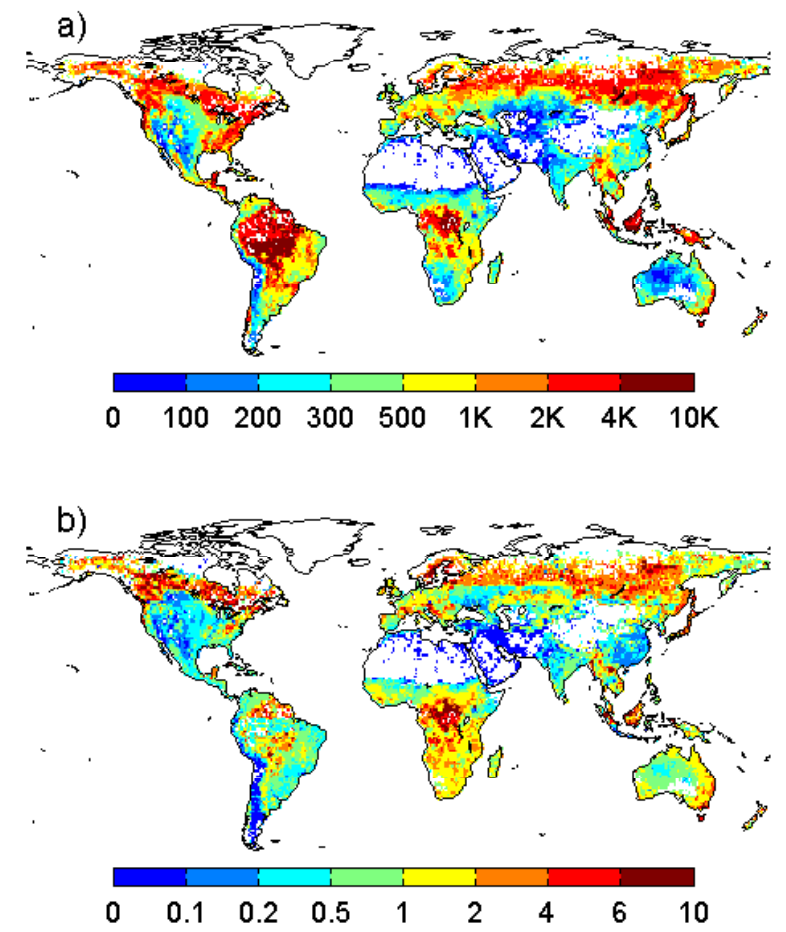

Fig. 5. (a) Fire emissions per $\mathrm{m}^{2}$ of burned area $\left(\mathrm{g} \mathrm{C} \mathrm{m}^{-2}\right.$ year $\left.^{-1}\right)$. (b) Emission per MODIS fire count $\left(\times 10^{6} \mathrm{kgC} \mathrm{year}^{-1}\right.$ firecount ${ }^{-1}$ ). Data is averaged over 2001-2004.

Average emissions for the eight year study period were calculated to be $2460 \mathrm{TgC}_{\mathrm{ear}}^{-1}$, corresponding to $8903 \mathrm{TgCO}_{2}$ year $^{-1}, \quad 433 \mathrm{Tg} \mathrm{CO}_{\text {year }}{ }^{-1}$, and $21 \mathrm{Tg} \mathrm{CH}_{4}$ year $^{-1}$ based on emission factors from Andreae and Merlet (2001) and Andreae (personal communication) as described in Sect. 2.5 (Table 5). As a measure of IAV, the standard deviation divided by the average (coefficient of variation, $\mathrm{CV}$ ) was 0.16 for annual carbon emissions, 0.16 for $\mathrm{CO}_{2}, 0.21$ for $\mathrm{CO}$, and 0.27 for $\mathrm{CH}_{4}$ (Table 5). Because forest fires emit higher amounts of reduced species per unit carbon consumed, the relatively high $\mathrm{CV}$ of $\mathrm{CO}$ and $\mathrm{CH}_{4}$ compared to $\mathrm{CO}_{2}$ is another indicator that IAV in emissions is largely driven by forest fires (Randerson et al., 2005). A map of mean annual emissions, averaged over the 1997-2004 period, is shown in Fig. 6. High levels of emissions occurred from well known biomass burning regions, including the boreal forests of North America and Eurasia, tropical America, Africa, Southeast Asia, and Australia. Fires were present in all biomes except low productivity deserts.

On a global scale, fire emissions accounted for $4.4 \%$ of the total carbon loss $\left(R_{h}+\right.$ fires $)$ from terrestrial ecosystems during 1997-2004 (Fig. 7). This carbon was originally fixed as NPP. The dominant loss pathway was $R_{h}$ (not shown). In frequently burning savanna grid cells, many of which are close to steady state over the study period in our model, ap-

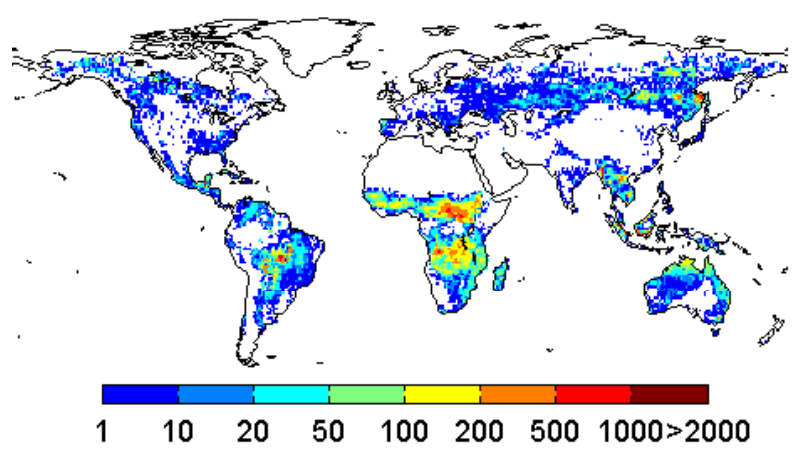

Fig. 6. Mean annual fire emissions $\left(\mathrm{g} \mathrm{C} \mathrm{m}^{-2}\right.$ year $\left.^{-1}\right)$ averaged over 1997-2004.

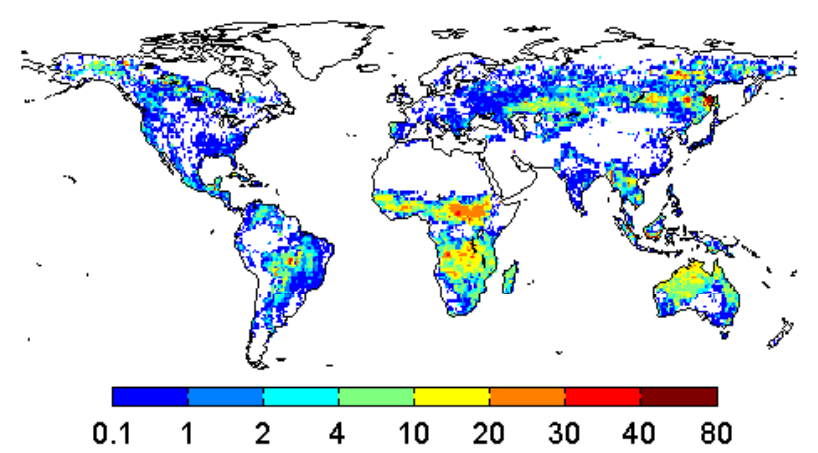

Fig. 7. Percentage of total carbon losses ( $R_{h}$ and fires) that was returned to the atmosphere via fire emissions, averaged over 19972004. Grid cells where the percentage approaches $80 \%$ indicate that fuels were burned that had accumulated for a longer period than the study interval, and that a large part of the grid cell burned during the study period.

proximately $20 \%$ of total ecosystem carbon losses occurred via fire emissions. In some boreal regions that burned extensively and in tropical forests undergoing rapid clearing, and where fuels accumulated over many decades prior to our study interval, the percentage of fire loss was even higher.

\subsection{Seasonal dynamics}

There was a clear distinction between the seasonality of fire emissions in boreal regions that usually burn during summer, and tropical regions that burn during the hemisphere's winter (Fig. 8). The burning season in the tropics was about 6 months out of phase with the annual movement of the Intertropical Convergence Zone (ITCZ). The seasonality of fire emissions in most regions was relatively constant throughout our study period. There were a few exceptions. In boreal Asia, maximum levels of fire emissions in 2002 occurred in August, while in 2003 maximum fire emissions occurred in May. Other studies using ground and 

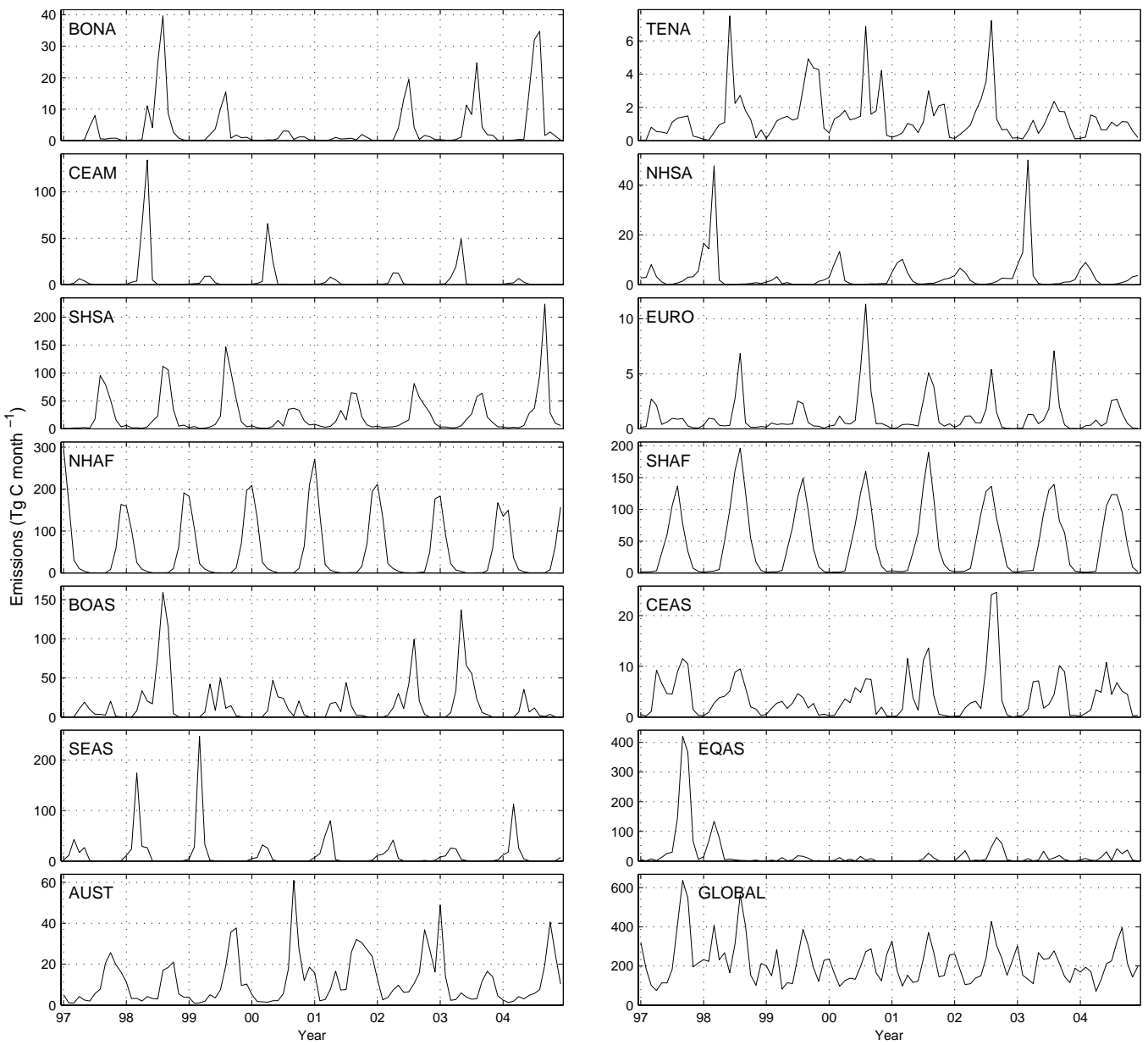

Fig. 8. Monthly fire emissions $\left(\mathrm{Tg} \mathrm{C}\right.$ month $^{-1}$ ) for the regions defined in Fig. 1 and Table 1 . Note that the seasonality in Africa during 1997-2000 was averaged from 2001-2004 (though the annual amplitude was allowed to vary).

satellite-based measurements of $\mathrm{CO}$ in the northern hemisphere have previously noted the difference in seasonality between the two years (Edwards et al., 2004; Yurganov et al., 2005). Another region where the seasonality of emissions varied substantially was Central Asia; two peaks are visible in some years $(1997,2001,2003)$ in Fig. 8, while in other years the first peak is less pronounced $(1998,2002)$. In Equatorial Asia, only in 1998 after the strong El Niño, was substantial fire activity observed during February and March; usually the peak fire season occurred later in the year during the August-October period.

Studies using measurements of atmospheric CO from MOPITT have identified a substantial mismatch in seasonal timing of top-down (inverse) estimates of $\mathrm{CO}$ fluxes vs. bottomup biogeochemical model estimates (Pétron et al., 2004; Arellano et al., 2006). In Fig. 9 we show results from Southern hemisphere Africa (SHAF) where the mismatch appeared largest. The MOPITT-derived approaches indicate that the peak fire season occurs in September; measurements of Aerosol Optical Depth (MOD08_M3, available online at http://modis-atmos.gsfc.nasa.gov/) indicate a peak a month later, in October (Fig. 9a). In contrast, both the GBA2000 burned area product and our previous emission estimates that were based on VIRS fire counts (GFEDv1; van der Werf et al., 2004) peaked in June or July, up to 4 months earlier (Fig. 9b). Even though the peak fire season shifts to August in our approach described here using MODIS fire counts, there is still a 1-2 month offset with respect to the atmospheric-based approaches. There are several possible reasons for this continued offset. First, the fire season in SHAF shifts through time from west to east. When dividing SHAF at longitude $25^{\circ} \mathrm{E}$, the fraction of total SHAF burned area that is observed west of $25^{\circ} \mathrm{E}$ is $48 \%$ for GBA2000, $46 \%$ for GFEDv1, and $41 \%$ for the burned area used in this study (Giglio et al., 2006). Greater burned area and emissions in the west causes the peak fire season for the entire region to advance to earlier times within the year. Another clue for the reasons behind this mismatch may come from 

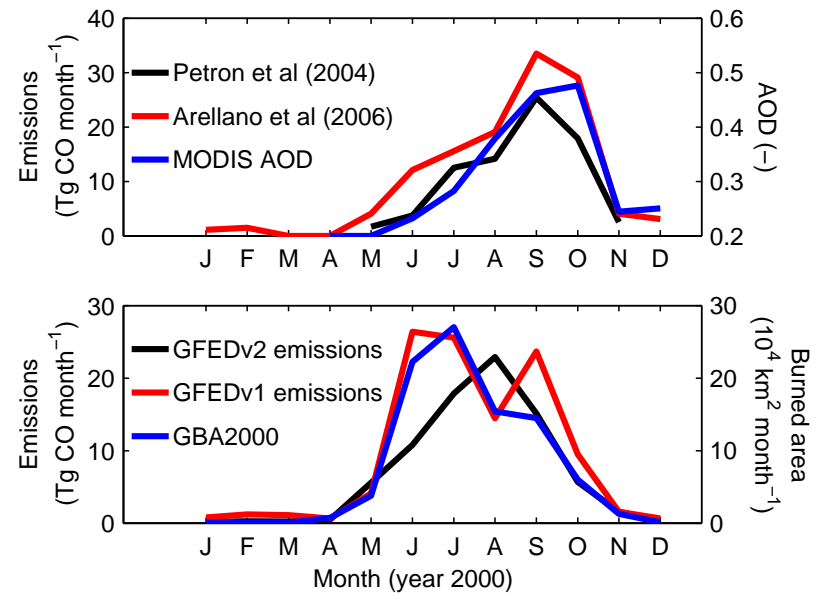

Fig. 9. Fire seasonality derived from different sources for southern hemisphere Africa (SHAF) for the year 2000. (a) "top down" derived seasonality using $\mathrm{CO}$ retrievals from the MOPITT sensor (Pétron et al., 2004; Arellano et al., 2006) and aerosol optical depth from MODIS. (b) "bottom-up" seasonality from this study (GFEDv2), our previous work (GFEDv1), and burned area from GBA2000 (Grégoire et al., 2002).

Table 5. Annual fire emissions of carbon, $\mathrm{CO}_{2}, \mathrm{CO}$, and $\mathrm{CH}_{4}$ in Tg year $^{-1}$.

\begin{tabular}{lcccc}
\hline Year & carbon & $\mathrm{CO}_{2}$ & $\mathrm{CO}$ & $\mathrm{CH}_{4}$ \\
\hline 1997 & 2991 & 10760 & 557 & 30 \\
1998 & 3183 & 11454 & 591 & 30 \\
1999 & 2284 & 8291 & 392 & 19 \\
2000 & 2038 & 7423 & 337 & 15 \\
2001 & 2224 & 8108 & 365 & 17 \\
2002 & 2386 & 8640 & 418 & 20 \\
2003 & 2251 & 8143 & 397 & 19 \\
2004 & 2320 & 8406 & 405 & 20 \\
Average & 2460 & 8903 & 433 & 21 \\
SD $^{1}$ & 403 & 1416 & 91 & 6 \\
$\mathrm{CV}^{2}$ & 0.16 & 0.16 & 0.21 & 0.27 \\
\hline
\end{tabular}

${ }^{1}$ Standard deviation.

${ }^{2}$ Coefficient of variation.

aerosol characteristics; late season aerosols have a higher albedo than aerosols in the beginning of the season (T. Eck, personal communication), which is likely to be the result of more burning in woodlands than in grasslands. Woodland fires emit larger amounts of $\mathrm{CO}$ per unit carbon burned than grassland fires, and this shift from grassland fires to woodland fires may not be captured by our coarse resolution modeling framework. Modeling at the MODIS native resolutions or even finer using other sensors may help in the future in identifying the role of these fine scale dynamics.
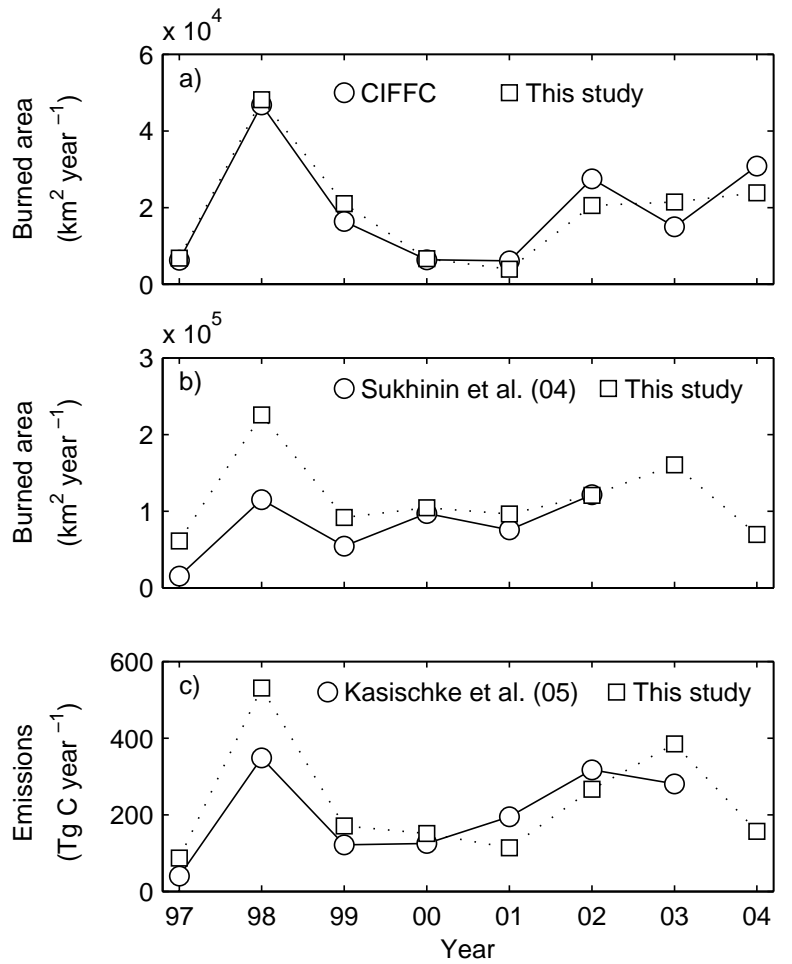

Fig. 10. Annual burned area for Canada (a) and Russia (b), and annual carbon emissions for the boreal region (c). Results from this study were compared to (a) burned area as compiled by the Canadian Interagency Forest Fire Centre (CIFFC), (b) burned area calculated using AVHRR data by Sukhinin et al. (2004), and (c) emissions from the "moderate severity scenario" from Kasischke et al. (2005) using various sources of burned area combined with the Boreal Wildland-Fire Emissions Model.

\subsection{Burned area}

The regions that burned most frequently during 19972004 were northern hemisphere Africa, southern hemisphere Africa, and Australia (Tables 4 and 6). Together, these three savanna areas accounted for approximately $80 \%$ of global burned area during our study period. The total burned area derived in this study for all of Africa is 2.4 million $\mathrm{km}^{2}$ year $^{-1}$ in 2000 , comparable to the 2.1 million $\mathrm{km}^{2}$ year ${ }^{-1}$ as calculated using another satellitebased approach (GBA2000, Grégoire et al., 2002). The difference in total burned area in Australia is somewhat larger: approximately 0.7 million $\mathrm{km}^{2}$ year ${ }^{-1}$ as calculated here vs. approximately 0.5 million $\mathrm{km}^{2}$ year ${ }^{-1}$ by GBA2000.

Detecting burned area in tropical deforestation areas represents a greater challenge, both because of consistent cloud cover and because of human manipulation of fire processes. Detailed burned area estimates associated with deforestation cannot be given, because of high heterogeneity within the $1^{\circ} \times 1^{\circ}$ grid cells we have used here, and because pasture 

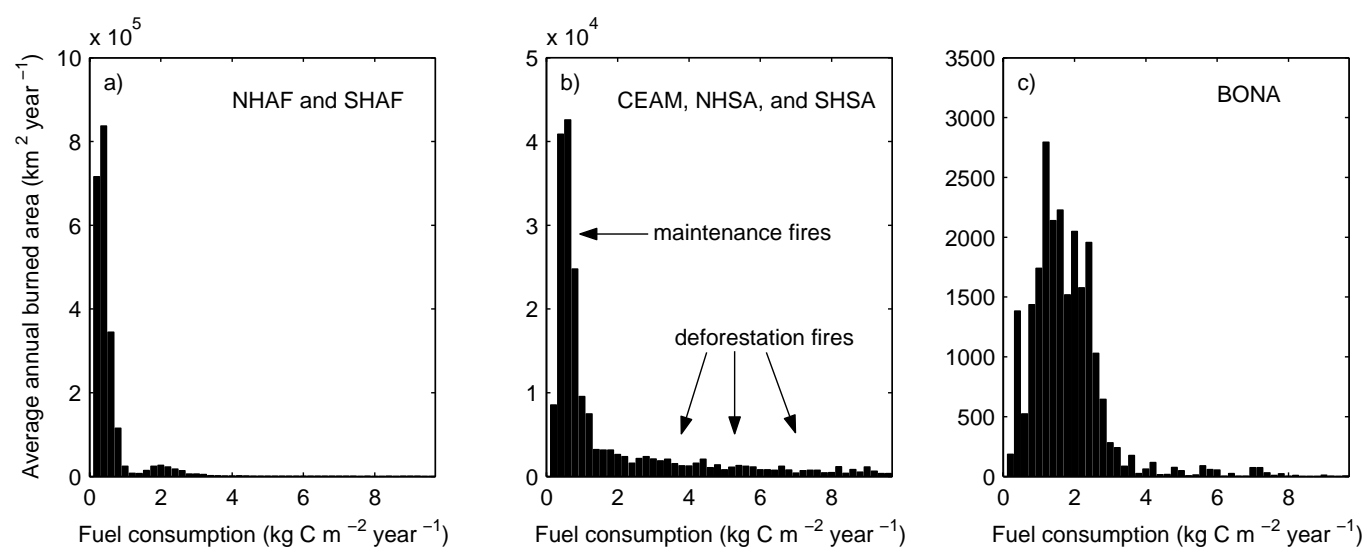

Fig. 11. Frequency of occurrence of fuel consumption in different regions, (a) Africa, (b) Central America, Northern Hemisphere South America, and Southern Hemisphere South America, and (c) boreal North America. Note the order of magnitude difference in vertical scale between the panels. Each bar represents a $0.2 \mathrm{~kg} \mathrm{C} \mathrm{m}^{-2}$ year ${ }^{-1}$ bin, centred upon its mean.

Table 6. Area burned $\left(\times 10^{4} \mathrm{~km}^{2}\right.$ year $^{-1}=$ Mha year $\left.^{-1}\right)$ for different regions and years.

\begin{tabular}{|c|c|c|c|c|c|c|c|c|c|c|c|}
\hline \multirow{2}{*}{ Region } & \multicolumn{8}{|c|}{ Year } & \multirow{2}{*}{ Average } & \multirow{2}{*}{ St.dev. } & \multirow{2}{*}{ St.dev./Average } \\
\hline & 1997 & 1998 & 1999 & 2000 & 2001 & 2002 & 2003 & 2004 & & & \\
\hline BONA & 1.5 & 4.9 & 2.3 & 0.7 & 0.4 & 2.6 & 2.3 & 4.0 & 2.3 & 1.5 & 0.66 \\
\hline TENA & 0.9 & 1.7 & 2.6 & 2.3 & 1.4 & 1.7 & 1.5 & 1.2 & 1.7 & 0.5 & 0.34 \\
\hline CEAM & 1.7 & 9.9 & 2.6 & 3.6 & 1.8 & 2.2 & 2.9 & 1.8 & 3.3 & 2.7 & 0.83 \\
\hline NHSA & 3.4 & 5.2 & 1.6 & 4.5 & 4.4 & 3.6 & 4.8 & 3.8 & 3.9 & 1.1 & 0.29 \\
\hline SHSA & 11.7 & 16.4 & 14.5 & 10.2 & 12.4 & 12.7 & 10.8 & 13.4 & 12.8 & 2.0 & 0.16 \\
\hline EURO & 1.7 & 2.6 & 1.6 & 4.1 & 2.9 & 1.6 & 2.6 & 1.9 & 2.4 & 0.9 & 0.36 \\
\hline MIDE & 0.1 & 0.1 & 0.3 & 0.2 & 0.6 & 0.5 & 0.4 & 0.4 & 0.3 & 0.2 & 0.54 \\
\hline NHAF & 157.8 & 135.8 & 149.1 & 153.7 & 153.2 & 135.2 & 125.5 & 129.8 & 142.5 & 12.3 & 0.09 \\
\hline SHAF & 65.1 & 97.8 & 72.8 & 76.5 & 84.0 & 82.4 & 79.6 & 75.3 & 79.2 & 9.6 & 0.12 \\
\hline BOAS & 5.4 & 19.8 & 8.2 & 9.1 & 6.3 & 9.3 & 14.5 & 4.9 & 9.7 & 5.1 & 0.52 \\
\hline CEAS & 21.1 & 15.7 & 8.6 & 12.8 & 16.5 & 26.7 & 17.1 & 18.9 & 17.2 & 5.4 & 0.31 \\
\hline SEAS & 8.9 & 21.1 & 23.0 & 8.8 & 10.8 & 10.2 & 8.4 & 16.1 & 13.4 & 5.9 & 0.44 \\
\hline EQAS & 16.7 & 5.3 & 1.1 & 0.8 & 0.8 & 3.4 & 1.4 & 2.9 & 4.0 & 5.3 & 1.32 \\
\hline AUST & 41.5 & 36.0 & 52.9 & 70.7 & 78.7 & 58.9 & 24.8 & 44.9 & 51.0 & 18.0 & 0.35 \\
\hline Global & 337.5 & 372.4 & 341.0 & 358.0 & 374.2 & 351.0 & 296.6 & 319.3 & 343.7 & 26.4 & 0.08 \\
\hline
\end{tabular}

fires within these grid cells will dominate the burned area numbers.

In boreal regions, our burned area time series was correlated with independent estimates for Canada from the Canadian Interagency Forest Fire Centre (CIFFC) and for Russia (Sukhinin et al., 2004), but the magnitude differed in Russia (Fig. 10). This may be a consequence of the way we extended the MODIS burned area time series back in time using ATSR fire counts. Since ATSR only detects fires at night and fire activity peaks during daytime, ATSR may more easily detect large fires that burn for longer periods. This is a potential reason for the higher burned area in the high fire year of 1998 in boreal Asia than reported by Sukhinin et al. (2004). This was not observed in Canada, where our burned area was similar to independently derived estimates.

\subsection{Fuel consumption}

Combustion completeness (CC) and fuel loads were inversely related; in general the higher the fuel loads, the lower CC (Table 4). This was because high fuel loads were often a result of an increased abundance of stem and coarse woody biomass that tend to combust incompletely (Table 3). Boreal regions and Equatorial Asia did not follow this trend; here organic soil carbon and peat represented a large fraction of the fuel load (Table 4). In boreal regions, biomass and litter 
pools were equally large, but a larger part of the emissions stemmed from the combustion of litter because of the higher $\mathrm{CC}$ observed for these fuels. CC was also high in deforestation regions (SHSA, for example) because we increased CC for stems and coarse woody debris when there were high levels of fire persistence to represent repeated human aggregation and burning of fuels.

The highest fuel loads $\left(\sim 10 \mathrm{~kg} \mathrm{C} \mathrm{m}^{-2}\right)$ were predicted to occur in Equatorial Asia, because of high aboveground fuel loads and peats in wetland areas. Other tropical areas where fires were being used to clear forests also had high fuel loads within burned areas, including Central and South America. In both boreal North America and boreal Asia, fuel loads were approximately $3.5 \mathrm{~kg} \mathrm{C} \mathrm{m}^{-2}$, and were almost evenly distributed between aboveground biomass and litter fuels. In savanna regions, fuel loads were highest in southern hemisphere Africa $\left(1.3 \mathrm{~kg} \mathrm{C} \mathrm{m}^{-2}\right)$ because a substantial part of the burning occurred in woodland areas, and were lowest in Australia $\left(0.4 \mathrm{~kg} \mathrm{C} \mathrm{m}^{-2}\right)$ where much of the burning occurred in low productivity grasslands. Fuel loads in northern hemisphere Africa $\left(0.7 \mathrm{~kg} \mathrm{C} \mathrm{m}^{-2}\right)$ fell in between these two regions.

In frequently burning savannas, there was a clear upper limit on fuel consumption. Most savannas that burned annually were the more productive savannas with NPP values of approximately $1000 \mathrm{~g} \mathrm{C} \mathrm{m}^{-2}$ year $^{-1}$ (van der Werf et al., 2003). Since half of the NPP was allocated belowground and was not accessible for fires, fuel loads in annual burning savannas were at most $500 \mathrm{~g} \mathrm{C} \mathrm{m}^{-2}$. However, not all above ground biomass was available for fires since microbes, herbivores, and humans also consume the available carbon. In addition to this upper threshold, there was also a lower threshold of approximately $100 \mathrm{~g} \mathrm{C} \mathrm{m}^{-2}$ that may represent the minimum levels of fuel necessary to sustain fire spread (van Wilgen and Scholes, 1997). We found that the majority of the fires in Africa consumed between 200 and $400 \mathrm{~g} \mathrm{C} \mathrm{m}^{-2}$ year $^{-1}$ (Fig. 11a), which is on the high end of most remote sensing and modeling studies (Scholes et al., 1996; Barbosa et al., 1999; Hély et al., 2003). In tropical America (CEAM, NHSA, SHSA) there was a clear distinction between pasture maintenance and savanna fires that accounted for much of the burned area but consumed little fuel, and deforestation fires with much larger fuel consumption but lower burned area (Fig. 11b). Pasture maintenance fires occur in managed grasslands and are ignited on purpose, mainly to prevent trees from invading the landscape and for nutrient recycling (Fearnside, 1990). In Africa, there were fewer fires with high fuel consumption ( $>3 \mathrm{~kg} \mathrm{C} \mathrm{m}^{-2}$ year $^{-1}$ ), providing evidence for less firedriven deforestation than in South America. Fuels consumed in the boreal ecosystems consisted primarily of litter and soil carbon (Table 4). In boreal North America, the majority of the fires consumed between 1 and $2.5 \mathrm{~kg} \mathrm{C} \mathrm{m}^{-2}$ year $^{-1}$, with a mean of $1.9 \mathrm{~kg} \mathrm{C} \mathrm{m}^{-2} \mathrm{year}^{-1}$, stemming largely from combustion of the duff layer and organic soil carbon, and with
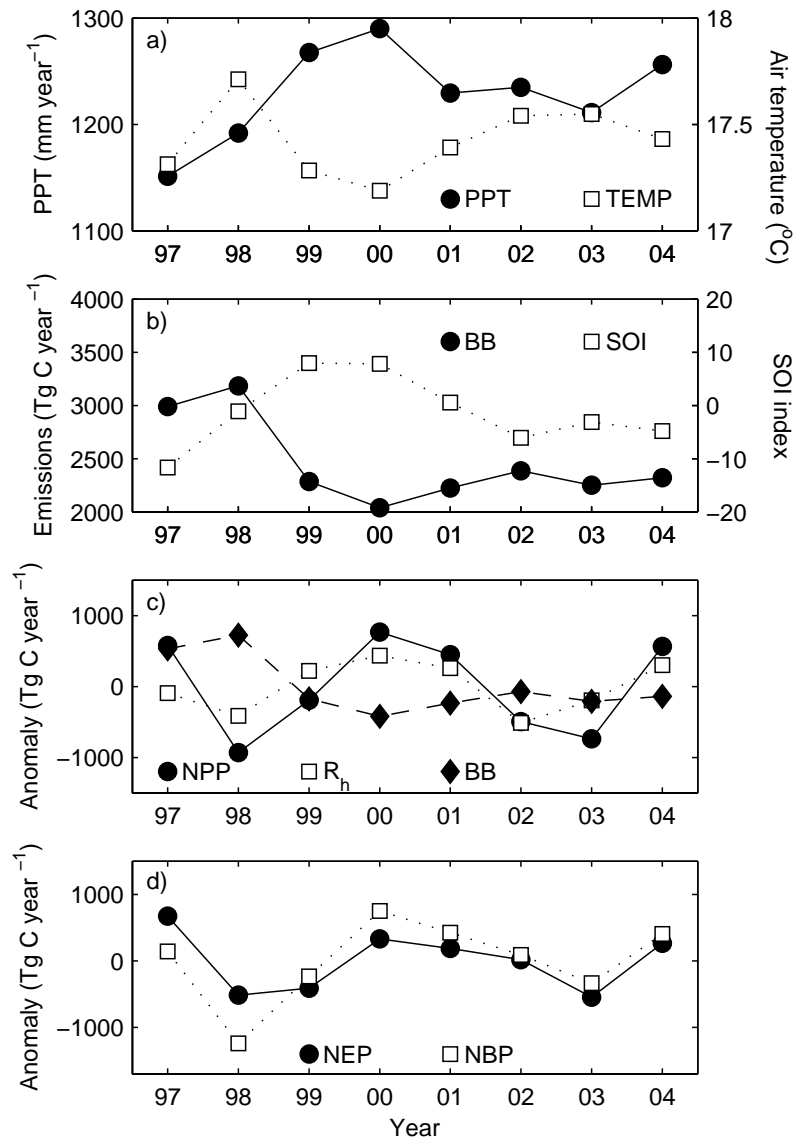

Fig. 12. Annual values of: (a) NPP-weighted precipitation (PPT) and air temperature (TEMP), (b) biomass burning (BB) emissions and Southern Oscillation Index (SOI, http://www.bom.gov. au/climate/current/soihtm1.shtml, (c) NPP, $R_{h}$, and biomass burning emission anomalies, and (d) net ecosystem production anomaly (NEP) and net biome production anomaly (NBP). Global fire emissions were negatively correlated with the SOI $(\mathrm{r}=-0.53)$.

minor contributions from stems and leaves (Fig. 11c). This distribution is similar to the modeled distribution reported by Amiro et al. (2001).

\subsection{Emissions}

Average annual emissions over the 8 year time period were $2.5 \mathrm{PgC}_{\text {year }}{ }^{-1}$ (Tables 5 and 7, Fig. 12b). African emissions accounted for $49 \%$ of the total and southern hemisphere South America contributed another 13\%. Other major contributors included Equatorial Asia (11\%), boreal regions (9\%), Southeast Asia (6\%), and Australia (6\%).

Over the 8 year period, there was significant IAV, especially during the first 4 years (Fig. 12b). Emissions in both 1997 and 1998 were approximately $1 \mathrm{PgC} \mathrm{year}^{-1}$ higher than in 2000. In contrast, global PPT was low in the second half of 1997 and in 1998 and at a maximum in 2000 (Adler 
Table 7. Fire emissions for different regions and years $\left(\mathrm{Tg} \mathrm{C}_{\mathrm{Cear}}{ }^{-1}\right)$.

\begin{tabular}{|c|c|c|c|c|c|c|c|c|c|c|c|}
\hline \multirow{2}{*}{ Region } & \multicolumn{8}{|c|}{ Year } & \multirow{2}{*}{ Average } & \multirow{2}{*}{ St.dev. } & \multirow{2}{*}{ St.dev./Average } \\
\hline & 1997 & 1998 & 1999 & 2000 & 2001 & 2002 & 2003 & 2004 & & & \\
\hline BONA & 16 & 93 & 37 & 11 & 7 & 45 & 55 & 90 & 44 & 34 & 0.76 \\
\hline TENA & 8 & 19 & 25 & 24 & 14 & 20 & 12 & 10 & 16 & 6 & 0.39 \\
\hline CEAM & 15 & 212 & 25 & 98 & 20 & 31 & 81 & 17 & 62 & 68 & 1.10 \\
\hline NHSA & 32 & 83 & 11 & 29 & 38 & 27 & 80 & 33 & 42 & 26 & 0.62 \\
\hline SHSA & 272 & 314 & 360 & 160 & 241 & 264 & 216 & 443 & 284 & 88 & 0.31 \\
\hline EURO & 9 & 14 & 8 & 25 & 14 & 13 & 15 & 10 & 14 & 5 & 0.39 \\
\hline MIDE & 0 & 0 & 1 & 0 & 1 & 1 & 1 & 1 & 1 & 0 & 0.46 \\
\hline NHAF & 740 & 565 & 606 & 665 & 720 & 615 & 541 & 562 & 627 & 75 & 0.12 \\
\hline SHAF & 465 & 721 & 535 & 567 & 606 & 568 & 581 & 565 & 576 & 72 & 0.12 \\
\hline BOAS & 71 & 438 & 134 & 140 & 107 & 221 & 330 & 66 & 188 & 133 & 0.71 \\
\hline CEAS & 60 & 45 & 26 & 37 & 49 & 72 & 45 & 45 & 47 & 14 & 0.29 \\
\hline SEAS & 102 & 265 & 314 & 73 & 159 & 97 & 77 & 182 & 159 & 90 & 0.57 \\
\hline EQAS & 1089 & 317 & 66 & 51 & 50 & 257 & 86 & 170 & 261 & 349 & 1.34 \\
\hline AUST & 111 & 96 & 136 & 157 & 199 & 156 & 131 & 127 & 139 & 32 & 0.23 \\
\hline Global & 2991 & 3183 & 2284 & 2038 & 2224 & 2386 & 2251 & 2320 & 2460 & 403 & 0.16 \\
\hline
\end{tabular}

et al., 2003, Fig. 12a). 1997 was a high fire year because of emissions in equatorial Asia, largely stemming from the combustion of peat in Indonesia (Page et al., 2002). 1998 was a high fire year because of increased burning across multiple continents, including equatorial Asia, boreal North America and Asia, and Central and South America. Only in northern hemisphere Africa and Australia were emissions below average (Table 7). During the final 4 years of the study period, the range of emissions was lower, but emissions were elevated from 2000.

By far the region with the largest IAV was equatorial Asia, both in absolute and in relative terms, with a standard deviation that was approximately 1.3 times larger than the average (Table 7). Emissions in 1997 were over 20 times higher than in the year 2000, indicating a strong dependence on local climate and/or human activity. Emissions in equatorial Asia were elevated again in 2002. More detailed inversion studies using MOPITT should further constrain the magnitude of these 2002 anomalies, and their impact on high $\mathrm{CO}_{2}$ growth rates observed during 2002 and 2003. Other regions with substantial IAV include boreal North America and Asia, Central America, and northern hemisphere South America. IAV in frequently burning Africa was low.

Most savanna and grassland fires occurred in Africa and Australia. Average annual emissions from Africa were $1203 \mathrm{Tg} \mathrm{C}_{\mathrm{year}}{ }^{-1}$, and emissions from northern hemisphere Africa ( $627 \mathrm{Tg} \mathrm{C}_{\text {year }}{ }^{-1}$ ) were somewhat higher than emissions from southern hemisphere Africa (576 $\mathrm{Tg} \mathrm{C}_{\mathrm{Cear}}{ }^{-1}$ ). Average fuel consumption on the other hand, was higher in southern hemisphere Africa largely because relatively more fires were detected in woodlands, whereas almost all the fires in northern hemisphere Africa occurred in grasslands with lower percentages of woody vegetation. Other studies have reported lower emissions (Scholes et al., 1996; Barbosa et al., 1999; Hoelzemann et al., 2004), but relatively higher IAV (Barbosa et al., 1999). Some of this difference can probably be attributed to higher fuel loads in our study as our burned area estimates are comparable or even lower than those reported in previous studies. Emissions calculated by Ito and Penner (2004) are comparable to our estimates, with a difference of about $10 \%$, depending on the scenario used by Ito and Penner (2004).

\subsection{Net biome productivity}

Average annual global NPP was $58 \mathrm{PgC}$ year $^{-1}$. Annual NPP and $R_{h}$ values were approximately 23 times larger than fire fluxes ( 58 vs. $2.5 \mathrm{Pg} \mathrm{C}_{\mathrm{year}}{ }^{-1}$ ). As a consequence, relatively small variations in the balance between NPP and $R_{h}$ can have a large effect on IAV of net biome productivity (NBP) and the $\mathrm{CO}_{2}$ growth rate. NPP was highest in 2000 and lowest in 1998 , with a difference of $1.8 \mathrm{PgC}_{\text {year }}{ }^{-1}$ (Fig. 12c). About 95\% of NPP was returned to the atmosphere via $R_{h}$ during 1997-2004. Variability of $R_{h}$ between years was similar to NPP, but with a smaller amplitude. The highest levels of $R_{h}$ were observed in 2000, and lowest in 1998 and 2002, with a difference of approximately 1.0 Pg C year ${ }^{-1}$.

Because NPP and $R_{h}$ tended to vary in parallel in CASA, the global net ecosystem production (NEP, NPP $-R_{h}$ ) was smaller than the anomalies in NPP. Large net uptake occurred in 1997, 2000, and 2004, while carbon was released during 1998 because the negative NPP anomaly was larger than the $R_{h}$ anomaly. In 2003 modelled variations in NPP and $R_{h}$ 
were somewhat different from other years; $R_{h}$ showed only a small negative anomaly while NPP was inhibited much more, leading to a source (Fig. 12c). The NEP signal was amplified by IAV in fires. The net result was that net biome production (NBP = NEP - fire emissions) had a larger amplitude than NEP. This was most evident during the first 5 years of the study period.

\subsection{Differences with earlier estimates}

Emission estimates from our earlier studies were released in 2004 as the "Global Fire Emissions Database" (GFED version 1), covering the 1997-2001 period. These estimates were compared to results from, or used as a priori information in, several inversion studies (Arellano et al., 2004; Pétron et al., 2004; van der Werf et al., 2004). The main limitations of GFEDv1 as indicated by inversion studies were the underestimation of emissions anomalies in Equatorial Asia, Central and northern South America, and in the boreal regions. Inversion analyses suggest that GFEDv1 overestimated the magnitude of southern Africa emissions and that the seasonal phasing of emission in this region was off by several months.

Discrepancies between the inversion studies and our bottom-up results may help to identify regions where the bottom-up approach has a problem representing biomass burning processes, assuming that the emission factors that translate the carbon emissions into the $\mathrm{CO}$ fluxes used in these inversions are correct (and that inversion don't suffer from other types of biases). One example is the combustion of peat that was not taken into account in GFEDv1, and may have been partly responsible for the underestimation of emissions from equatorial Asia.

There are numerous differences between the results presented here and those previously reported in GFEDv1, mainly stemming from the use of improved burned area and the inclusion of organic soil carbon and peat burning. For GFEDv1 we used a single global relationship between fire counts, fraction tree cover, and burned area. Here, many more MODIS scenes with burned area were available for fire count calibration (446), allowing us to use regionallybased fire count to burned area relationships that depended on fire count cluster size and fire persistence, in addition to fractional tree cover (Giglio et al., 2006). This has led to a decrease of Southern African emissions because of lower burned area. The inclusion of organic soil carbon and peat burning increased emissions in boreal regions and in equatorial Asia. Another difference is that we formerly had a broad band of relatively low emissions around the main deforestation areas in South America and Indonesia, our new results indicate that the emissions are higher in a smaller band known to have high rates of clearing (e.g., Mato Grosso, southern and eastern Kalimantan). However, total emissions in Central and Southern America are lower in our current inventory, and diverge from results obtained from inverse stud- ies (that suggested our previous dataset underestimated emissions in these regions; Arellano et al., 2006).

\subsection{Uncertainties}

\subsubsection{Burned area}

Burned area estimates have only recently become available from different satellite sensors, allowing for a comparison of different approaches. In boreal and tropical savanna ecosystems, independent estimates of burned area are converging, for large regions within $20 \%$, although interannual differences can be larger. Obviously this does not rule out the possibility that independent products can suffer from identical biases, but it does provide some optimism compared to earlier estimates that differed by over a factor 2 (Kasischke and Penner, 2004).

In deforestation regions, burned area estimates remain poorly constrained. There are several reasons for this, the most important being consistent cloud cover and mechanized aggregation of fuels into piles that make burned area detection problematic. The approach of Giglio et al. (2006) detects more burned area in areas undergoing active deforestation than other published estimates (Grégoire et al., 2002; Simon et al., 2004), but it remains unclear how to assess uncertainty levels associated with this product. With greater use of high resolution satellite data it the future, it is likely that burned area estimates will increase, especially in closedcanopy tropical forest ecosystems (Silva et al., 2005).

Because we used a statistical approach to estimate burned area from fire counts (Giglio et al., 2006), burned area estimates were available only for coarse resolution grid cells. This may introduce a bias when fire processes show spatial heterogeneity. Future studies of global biomass burning emissions will profit from comparisons with studies that use burned area at finer resolution, ideally employing methods to scale up from fine to coarse resolutions.

\subsubsection{Fuel loads}

As burned area estimates improve from higher resolution satellite data and refined algorithms, uncertainties in fuel loads may become the limiting factor in estimating emissions (French et al., 2004; Hoelzemann et al., 2004). Although using satellite data has improved estimates of spatial and temporal variability in fuel loads, approaches for calibrating these estimates using measured values are still in their infancy. Reasons for this include a mismatch in scale between the measurements at plot level and the much coarser model grid cell, and a lack of data. Calibrating against satellite-based measurements of, for example, biomass estimates based on satellite measured vegetation height are likely to contribute to decreasing uncertainties. Following Amiro et al. (2001) and Hély et al. (2003), we have presented histograms of carbon consumption (Fig. 11). These 
histograms illustrate the relationship between burned area, fuel consumption, and vegetation type or region and provide an efficient means to directly compare carbon consumption between global models and more region-specific models, as well as with field measurements.

\subsubsection{Emissions}

At a global scale, perhaps the strongest constraints on total emission from fires come from inversion studies that utilize atmospheric CO measurements. Using MOPITT observations, an atmospheric model, and emission factors from Andreae and Merlet (2001), Arellano et al. (2006) estimated that global fire emissions for the April 2000 through March 2001 period were $3.4 \pm 1.0 \mathrm{PgC} \mathrm{year}^{-1}$. This global estimate is considerably higher than several recent bottom-up emission estimates. For example, Hoelzemann et al. (2004) estimated emissions for the year 2000 to be $1.7 \mathrm{PgC}_{\text {year }}{ }^{-1}$, while Ito and Penner's (2004) estimate was $1.3 \mathrm{Pg} \mathrm{C}_{\text {year }}{ }^{-1}$, also for 2000. In the same year, our estimate was $2.0 \mathrm{PgC} \mathrm{year}^{-1}$. Reconciling differences between bottom-up and top-down emissions estimates is a clear research priority, and one that may benefit from expanding sets of atmospheric observations from MOPITT, SCIAMACHY, and the planned Orbiting Carbon Observatory.

\section{Conclusions}

We have provided new constraints on biomass burning emissions over the 1997-2004 period, using improved satellitederived information on seasonality and extent of burning, and a more complete fuel load parameterization. The main conclusions from this study can be summarized as follows:

1. Average annual biomass burning emissions as calculated by our model were $2.5 \mathrm{Pg} \mathrm{C}_{\text {year }}{ }^{-1}$ over the $1997-$ 2004 period. The dominant contributors were Africa (49\%), South America (13\%), equatorial Asia (11\%), boreal regions (9\%), and Australia (6\%).

2. Interannual variability over the 8 year period was large, especially in the first 4 years. Emissions in the years 1997 and 1998 were approximately $1 \mathrm{Pg} \mathrm{C}$ year $^{-1}$ higher than emissions in 2000, following the ENSO pattern. 1997 was large because of the combustion of peat in equatorial Asia, 1998 was large because almost all major biomass burning regions showed increased emissions. We found that the largest interannual variability occurred in Equatorial Asia, with a standard deviation that was 1.3 times as large as the annual mean for that region. In contrast, interannual variability in Africa was relatively low, with a standard deviation of only 0.1 times the average. During 1997-2004, global fire emissions were negatively correlated with the SOI.
3. Annual burned area and fire emissions were largely decoupled at a global scale over the 1997-2004 period because of differences in fuel loads between forests and grasslands. On a global scale, burned area was dominated by savannas, but interannual variability of burned area was relatively larger in forested ecosystems. This interannual variability, combined with the much higher fuel loads in forests, was responsible for most of the interannual variability in global emissions.

4. The seasonality of our estimates more closely matched the seasonality derived from atmospheric measurements of $\mathrm{CO}$ and aerosols than our previous estimates and other bottom-up estimates. However, there is still a mismatch of 1-2 months in southern hemisphere Africa. A potential reason for this could be a shift from grassland fires early in the dry season to woodland fires later in the dry season, a pattern that may not be captured by our coarse resolution modeling framework.

5. Uncertainties in biomass burning estimates are highest in deforestation regions and in regions where peat fires occur. Although the estimates presented in this study were based on an improved burned area dataset and fuel loads were modelled more realistically, top-down inversion methods are still needed to further constrain and refine these estimates. In this respect, multi-species inversions may be particularly effective in lowering systematic errors stemming from biases in emissions factors. Especially in deforestation regions and in other regions where spatial heterogeneity is large, finer resolution bottom-up modeling also has the potential to substantially reduce uncertainties.

6. Variations in global NPP and $R_{h}$ followed variations in global precipitation, with increased NPP and $R_{h}$ during wet spells and vice versa. Since the amplitude of NPP variations exceeded $R_{h}$, drought years resulted in $\mathrm{CCO}_{2}$ source. This was most evident during the first 5 years of the study period. This effect amplified the signal to the atmosphere from biomass burning (or vice versa).

Acknowledgements. We thank J. E. Pinzón and M. E. Brown from NASA Goddard's Global Inventory Modeling and Mapping Studies (GIMMS) for providing the NDVI time series, and E. S. Kasischke for helpful discussion about biomass burning in boreal regions. This work was supported by NASA grant NNG04GK49G to J. T. Randerson and NASA grant NNG04GD89G to P. S. Kasibhatla. GRvdW is supported by CarboEurope and the Laboratoire des Sciences du Climat et l'Environnement (LSCE), Gif sur Yvette, France.

The emission estimates presented here (carbon and several trace gas and aerosol species), as well as burned area, fuel loads, and combustion completeness values can be downloaded from http://ess1.ess.uci.edu/ $\ \%$ 7Ejranders/data/GFED2/.

Edited by: S. Quegan 


\section{References}

Adler, R. F., Huffman, G. J., Chang, A., Ferraro, R., Xie, P. P., Janowiak, J., Rudolf, B., Schneider, U., Curtis, S., Bolvin, D., Gruber, A., Susskind, J., Arkin, P., and Nelkin, E.: The version2 global precipitation climatology project (GPCP) monthly precipitation analysis (1979-present), J. Hydrometeorol., 4, 11471167, 2003.

Amiro, B. D., Todd, J. B., Wotton, B. M., Logan, K. A., Flannigan, M. D., Stocks, B. J., Mason, J. A., Martell, D. L., and Hirsch, K. G.: Direct carbon emissions from Canadian forest fires, 19591999, Canadian J. Forest Res., 31, 512-525, 2001.

Andreae, M. O. and Merlet, P.: Emission of trace gases and aerosols from biomass burning, Global Biogeochem. Cycles, 15, 955966, 2001.

Arellano, A. F., Kasibhatla, P. S., Giglio, L., van der Werf, G. R., and Randerson, J. T.: Topdown estimates of global CO sources using MOPITT measurements, Geophys. Res. Lett., 31, L01104, doi:10.1029/2003GL018609, 2004.

Arellano, A. F., Kasibhatla, P. S., Giglio, L., van der Werf, G. R., Randerson, J. T., and Collatz, G. J.:, Time-dependent inversion estimates of global biomass-burning $\mathrm{CO}$ emissions using Measurement of Pollution in the Troposphere (MOPITT) measurements, J. Geophys. Res., 111, D09303, doi:10.1029/2005JD006613, 2006.

Arino, O., Rosaz, J.-M., and Goloub, P.: The ATSR World Fire Atlas. A synergy with "Polder" aerosol products, Earth Obs. Quarterly, 1-6, 1999.

Bacastow, R. B.: Modulation of atmospheric carbon-dioxide by Southern Oscillation, Nature, 15 261, 116-118, 1976.

Balzter, H., Gerard, F. F., George, C. T., Rowland, C. S., Jupp, T. E., McCallum, I., Shvidenko, A., Nilsson, S., Sukhinin, A., Onuchin, A., and Schmullius, C.: Impact of the Arctic Oscillation pattern on interannual forest fire variability in Central Siberia, Geophys. Res. Lett., 32, L14709, doi:10.1029/2005GL022526, 2005.

Barbosa, P. M., Stroppiana, D., Grégoire, J. M., and Pereira, J. M. C.: An assessment of vegetation fire in Africa (19811991): Burned areas, burned biomass, and atmospheric emissions, Global Biogeochem. Cycles , 13, 933-950, 1999.

Batjes, N. H.: Total carbon and nitrogen in the soils of the world, Eur. J. Soil Sci., 47, 151-163, 1996.

Battle, M., Bender, M. L., Tans, P. P., White, J. W. C., Ellis, J. T., Conway, T., and Francey, R. J.: Global carbon sinks and their variability inferred from atmospheric O-2 and delta C-13, Science, 287, 2467-2470, 2000.

Bishop, J. K. B. and Rossow, W. B.: Spatial and temporal variability of global surface solar irradiance, J. Geophys. Res.-Oceans, 96, 839-858, 1991.

Bousquet, P., Peylin, P., Ciais, P., Le Quere, C., Friedlingstein, P., and Tans, P. P.: Regional changes in carbon dioxide fluxes of land and oceans since 1980, Science, 290, 1342-1346, 2000.

Carrasco, J. J., Neff, J. C., and Harden, J. W.: Modeling physical and biogeochemical controls over carbon accumulation in a boreal forest soil, J. Geophys. Res. - Biogeosci., 111, G02004, doi:10.1029/2005JG000087, 2006.

Carvalho, J. A., Santos, J. M., Santos, J. C., and Leitao, M. M.: A tropical rain-forest clearing experiment by biomass burning in the Manaus region, Atmos. Environ., 29, 2301-2309, 1995.

Ciais, P., Reichstein, M., Viovy, N., Granier, A., Ogee, J., Allard, V.,
Aubinet, M., Buchmann, N., Bernhofer, C., Carrara, A., Chevalier, F., De Noblet, N., Friend, A. D., Friedlingstein, P., Grunwald, T., Heinesch, B., Keronen, P., Knohl, A., Krinner, G., Loustau, D., Manca, G., Matteucci, G., Miglietta, F., Ourcival, J. M., Papale, D., Pilegaard, K., Rambal, S., Seufert, G., Soussana, J. F., Sanz, M. J., Schulze, E. D., Vesala, T., and Valentini, R.: Europe-wide reduction in primary productivity caused by the heat and drought in 2003, Nature, 437, 529-533, 2005.

Duncan, B. N., Martin, R. V., Staudt, A. C., Yevich, R., and Logan, J. A.: Interannual and seasonal variability of biomass burning emissions constrained by satellite observations, J. Geophys. Res.-Atmos., 108, 4100, doi:10.1029/2002JD002378, 2003.

Edwards, D. P., Emmons, L. K., Hauglustaine, D. A., Chu, D. A., Gille, J. C., Kaufman, Y. J., Pétron, G., Yurganov, L. N., Giglio, L., Deeter, M. N., Yudin, V., Ziskin, D. C., Warner, J., Lamarque, J. F., Francis, G. L., Ho, S. P., Mao, D., Chen, J., Grechko, E. I., and Drummond, J. R.: Observations of carbon monoxide and aerosols from the Terra satellite: Northern Hemisphere variability, J. Geophys. Res.-Atmos., 109, D24202, doi:10.1029/2004JD004727, 2004.

Fearnside, P. M.: Fire in the tropical rain forest of the Amazon basin, in: Fire in the tropical biota: ecosystem processes and global challenges, edited by: Goldammer, J. G., 106-116, Ecological Studies, 84, Springer-Verlag, Berlin, Germany, 1990.

Field, C. B., Randerson, J. T., and Malmstrom, C. M.: Global net primary production - Combining ecology and remote-sensing, Remote Sens. Environ., 51, 74-88, 1995.

Flannigan, M. D., Logan, K. A., Amiro, B. D., Skinner, W. R., and Stocks, B. J.: Future area burned in Canada, Climatic Change, 72, 1-16, 2005.

French, N. H. F., Goovaerts, P., and Kasischke, E. S.: Uncertainty in estimating carbon emissions from boreal forest fires, J. Geophys. Res., 109, D14S08, doi:10.1029/2003JD003635, 2004.

Giglio, L., Descloitres., J., Justice, C. O., and Kaufman, Y. J.: An enhanced contextual fire detection algorithm for MODIS, Remote Sens. Environ, 87(2-3), 273-282, 15 October, 2003a

Giglio, L., Kendall, J. D., and Mack, R.: A multi-year active fire dataset for the tropics derived from the TRMM VIRS, Int. J. Remote Sens., 24, 4505-4525, 2003b.

Giglio, L., van der Werf, G. R., Randerson, J. T., Collatz, G. J., and Kasibhatla, P. S.: Global estimation of burned area using MODIS active fire observations, Atmos. Chem. Phys., 6, 957-974, 2006, http://www.atmos-chem-phys.net/6/957/2006/.

Gill, A. M.: Fire adaptive traits of vascular plants, in: Fire Regimes and Ecosystem Properties, edited by: Mooney, H. A., Bonnickson, J. M., Christensen, N. L., Lotan, J. E., and Reiners, W. A., 208-230, U.S. Dep. Agric. Forest Sci. General Technical Report, Washington, D.C., 1981.

Goulden, M. L., Munger, J. W., Fan, S. M., Daube, B. C., and Wofsy, S. C.: Exchange of carbon dioxide by a deciduous forest: Response to interannual climate variability, Science, 271, 1576-1578, 1996.

Goulden, M. L., Wofsy, S. C., Harden, J. W., Trumbore, S. E., Crill, P. M., Gower, S. T., Fries, T., Daube, B. C., Fan, S. M., Sutton, D. J., Bazzaz, A., and Munger, J. W.: Sensitivity of boreal forest carbon balance to soil thaw, Science, 279, 214-217, 1998.

Grégoire, J.-M., Tansey, K., and Silva, J. M. N.: The GBA2000 initiative: Developing a global burned area database from SPOTVEGETATION imagery, Int. J. Remote Sens., 24, 1369-1376, 
2002.

Hansen, J., Ruedy, R., Glascoe, J., and Sato, M.: GISS analysis of surface temperature change, J. Geophys. Res.-Atmos., 104, 30 997-31 022, 1999.

Hansen, M. C., DeFries, R. S., Townshend, J. R. G., Carroll, M., Dimiceli, C., and Sohlberg, R.: Global percent tree cover at a spatial resolution of 500 meters: First results of the MODIS vegetation continuous fields algorithm, Earth Interactions, 7, 1-15, 2003.

Hély, C., Dowty, P. R., Alleaume, S., Caylor, K. K., Korontzi, S., Swap, R. J., Shugart, H. H., and Justice, C. O.: Regional fuel load for two climatically contrasting years in southern Africa, J. Geophys. Res.-Atmos., 108, 8475, doi:10.1029/2002JD002341, 2003.

Hess, J. C., Scott, C. A., Hufford, G. L., and Fleming, M. D.: El Niño and its impact on fire weather conditions in Alaska, Int. J. Wildland Fire, 10, 1-13, 2001.

Hoelzemann, J. J., Schultz, M. G., Brasseur, G. P., Granier, C., and Simon, M.: Global Wildland Fire Emission Model (GWEM): Evaluating the use of global area burnt satellite data, J. Geophys. Res.-Atmos., 109, D14S04 doi:10.1029/2003JD003666, 2004.

Hoffa, E. A., Ward, D. E., Hao, W. M., Susott, R. A., and Wakimoto, R. H.: Seasonality of carbon emissions from biomass burning in a Zambian savanna, J. Geophys. Res.-Atmos., 104, 13 841$13853,1999$.

Houghton, R. A., Lawrence, K. T., Hackler, J. L., and Brown, S.: The spatial distribution of forest biomass in the Brazilian Amazon: a comparison of estimates, Global Change Biol., 7, 731746, 2001.

Ichoku, C. and Kaufman, Y. J.: A method to derive smoke emission rates from MODIS fire radiative energy measurements, IEEE Transact. Geosci. Remote Sensing, 43, 2636-2649, 2005.

Ito, A. and Penner, J. E.: Global estimates of biomass burning emissions based on satellite imagery for the year 2000, J. Geophys. Res. Atmos., 109, D14S05, doi:10.1029/2003JD004423, 2004.

Kanamitsu, M., Ebisuzaki, W., Woollen, J., Yang, S. K., Hnilo, J. J., Fiorino, M., and Potter, G. L.: NCEP-DOE AMIP-II reanalysis (R-2), Bull. Am. Meteorol. Soc., 83, 1631-1643, 2002.

Kasischke, E. S., Hyer, E. J., Novelli, P. C., Bruhwiler, L. P., French, N. H. F., Sukhinin, A. I., Hewson, J. H., and Stocks, B. J.: Influences of boreal fire emissions on Northern Hemisphere atmospheric carbon and carbon monoxide, Global Biogeochem. Cycles, 19, GB1012, doi:10.1029/2004GB002300, 2005.

Kasischke, E. S. and Penner, J. E.: Improving global estimates of atmospheric emissions from biomass burning, J. Geophys. Res.Atmos., 109, D14S01, doi:10.1029/2004JD004972, 2004.

Keeling, C. D., Whorf, T. P., Wahlen, M., and Vanderplicht, J.: Interannual extremes in the rate of rise of atmospheric carbondioxide since 1980, Nature, 375, 666-670, 1995.

Korontzi, S., Justice, C. O., and Scholes, R. J.: Influence of timing and spatial extent of savanna fires in southern Africa on atmospheric emissions, J. Arid Env., 54, 395-404, 2003.

Langenfelds, R. L., Francey, R. J., Pak, B. C., Steele, L. P., Lloyd, J., Trudinger, C. M., and Allison, C. E.: Interannual growth rate variations of atmospheric $\mathrm{CO}_{2}$ and its delta $\mathrm{C}-13, \mathrm{H}_{2}, \mathrm{CH}_{4}$, and CO between 1992 and 1999 linked to biomass burning, Global Biogeochem. Cycles, 16, 1048, doi:10.1029/2001GB001466, 2002.

Le Toan, T., Quegan, S., Woodward, I., Lomas, M., Delbart, N., and
Picard, G.: Relating radar remote sensing of biomass to modelling of forest carbon budgets, Climatic Change, 67, 379-402, 2004.

Lee, K., Wanninkhof, R., Takahashi, T., Doney, S. C., and Feely, R. A.: Low interannual variability in recent oceanic uptake of atmospheric carbon dioxide, Nature, 396, 155-159, 1998.

Leemans, R. and Cramer, W.: The IIASA database for mean monthly values of temperature, precipitation and cloudiness of a global terrestrial grid. International Institute for Applied Systems Analysis (IIASA), RR-91-18., 1991.

Los, S. O., Collatz, G. J., Sellers, P. J., Malmstrom, C. M., Pollack, N. H., DeFries, R. S., Bounoua, L., Parris, M. T., Tucker, C. J., and Dazlich, D. A.: A global 9-yr biophysical land surface dataset from NOAA AVHRR data, J. Hydrometeorol., 1, 183199, 2000.

Matthews, E. and Fung, I.: Methane emission from natural wetlands: Global area, distribution and environmental characteristics of sources, Global Biogeochem. Cycles, 1, 61-86, 1987.

Novelli, P. C., Masarie, K. A., Lang, P. M., Hall, B. D., Myers, R. C., and Elkins, J.W.: Re-analysis of tropospheric CO trends: Effects of the 1997-1998 wild fires, J. Geophys. Res. Atmos., 108, 4464, doi:10.1029/2002JD003031, 2003.

Oechel, W. C., Hastings, S. J., Vourlitis, G., Jenkins, M., Riechers, G., and Grulke, N.: Recent change of Arctic tundra ecosystems from a net carbon-dioxide sink to a source, Nature, 30 361, 520523, 1993.

Olson, R., Scurlock, J., Prince, S., Zheng, D., and Johnson, K. (Eds.): NPP multi-biome: NPP and driver data for ecosystem model-data intercomparison. Available on-line (http://www. daac.ornl.gov) from the Oak Ridge National Laboratory Distributed Active Archive Center, Oak Ridge, Tennessee, USA, 2001.

Page, S. E., Siegert, F., Rieley, J. O., Boehm, H. D. V., Jaya, A., and Limin, S.: The amount of carbon released from peat and forest fires in Indonesia during 1997, Nature, 420, 61-65, 2002.

Pétron, G., Granier, C., Khattatov, B., Yudin, V., Lamarque, J. F., Emmons, L., Gille, J., and Edwards, D. P.: Monthly CO surface sources inventory based on the 20002001 MOPITT satellite data, Geophys. Res. Lett., 31, L21107, doi:10.1029/2004GL020560, 2004.

Pinzón, J. E., Brown, M. E., and Tucker, C. J.: EMD correction of orbital drift artifacts in satellite data stream, Chapter 8, Part II. Applications, in: Hilbert-Huang transform and its applications, edited by: Huang, N. E. and Shen, S. S., World Scientific, Singapore, 167-186, 2005.

Plummer, S., Arino, O., Simon, M., and Steffen, W.: Establishing an earth observation product service for the terrestrial carbon community: the GLOBCARBON initiative, Mitigation and adaptation strategies for global change, 11, 97-111, 2006.

Potter, C. S., Randerson, J. T., Field, C. B., Matson, P. A., Vitousek, P. M., Mooney, H. A., and Klooster, S. A.: Terrestrial ecosystem production - A process model based on global satellite and surface data, Global Biogeochem. Cycles, 7, 811-841, 1993.

Randerson, J. T., Thompson, M. V., Malmstrom, C. M., Field, C. B., and Fung, I. Y.: Substrate limitations for heterotrophs: Implications for models that estimate the seasonal cycle of atmospheric $\mathrm{CO}_{2}$, Global Biogeochem. Cycles, 10, 585-602, 1996.

Randerson, J. T., van der Werf, G. R., Collatz, G. J., Giglio, L., Still, C. J., Kasibhatla, P., Miller, J. B., White, J. W. C., DeFries, 
R. S., and Kasischke, E. S.: Fire emissions from C-3 and C-4 vegetation and their influence on interannual variability of atmospheric $\mathrm{CO}_{2}$ and delta $\left(\mathrm{CO}_{2}\right)-\mathrm{C}-13$, Global Biogeochem. Cycles, 19, GB2019, doi:10.1029/2004GB002366, 2005.

Roberts, G., Wooster, M. J., Perry, G. L. W., Drake, N., Rebelo, L. M., and Dipotso, F.: Retrieval of biomass combustion rates and totals from fire radiative power observations: Application to southern Africa using geostationary SEVIRI imagery, J. Geophys. Res.-Atmos., 110, D21111, doi:10.1029/2005JD006018, 2005.

Saatchi, S., Agosti, D., Alger, K., Delabie, J., and Musinsky, J.: Examining fragmentation and loss of primary forest in the southern Bahian Atlantic forest of Brazil with radar imagery, Conservation Biol., 15, 867-875, 2001.

Saleska, S. R., Miller, S. D., Matross, D. M., Goulden, M. L., Wofsy, S. C., da Rocha, H. R., de Camargo, P. B., Crill, P., Daube, B. C., de Freitas, H. C., Hutyra, L., Keller, M., Kirchhoff, V., Menton, M., Munger, J. W., Pyle, E. H., Rice, A. H., and Silva, H.: Carbon in amazon forests: Unexpected seasonal fluxes and disturbance-induced losses, Science, 302, 1554-1557, 2003.

Schimel, D. and Baker, D.: Carbon cycle: The wildfire factor, Nature, 420, 29-30, 2002.

Scholes, R. J., Kendall, J., and Justice, C. O.: The quantity of biomass burned in southern Africa, J. Geophys. Res. Atmos, 101, 23 667-23 676, 1996.

Schuur, E. A. G.: Productivity and global climate revisited: The sensitivity of tropical forest growth to precipitation, Ecology, 84, 1165-1170, 2003.

Shea, R. W., Shea, B. W., Kauffman, J. B., Ward, D. E., Haskins, C. I., and Scholes, M. C.: Fuel biomass and combustion factors associated with fires in savanna ecosystems of South Africa and Zambia, J. Geophys. Res. Atmos., 101, 23 551-23 568, 1996.

Silva, J. M. N., Sa, A. C. L., and Pereira, J. M. C.: Comparison of burned area estimates derived from SPOT-VEGETATION and Landsat ETM plus data in Africa: Influence of spatial pattern and vegetation type, Remote Sens. Environ., 96, 188-201, 2005.

Simon, M., Plummer, S., Fierens, F., Hoelzemann, J. J., and Arino, O.: Burnt area detection at global scale using ATSR-2: The GLOBSCAR products and their qualification, J. Geophys. Res.Atmos., 109, D14S02, doi:10.1029/2003JD003622, 2004.

Stocks, B. J., Mason, J. A., Todd, J. B., Bosch, E. M., Wotton, B. M., Amiro, B. D., Flannigan, M. D., Hirsch, K. G., Logan, K. A., Martell, D. L., and Skinner, W. R.: Large forest fires in Canada, 1959-1997, J. Geophy. Res., 108, 8149, doi:10.1029/2001JD000484, 2002.
Sukhinin, A. I., French, N. H. F., Kasischke, E. S., Hewson, J. H., Soja, A. J., Csiszar, I. A., Hyer, E. J., Loboda, T., Conrad, S. G., Romasko, V. I., Pavlichenko, E. A., Miskiv, S. I., and Slinkina, O. A.: AVHRR-based mapping of fires in Russia: New products for fire management and carbon cycle studies, Remote Sens. Environ., 93, 546-564, 2004.

Thonicke, K., Prentice, I., and Hewitt, C.: Modeling glacial-interglacial changes in global fire regimes and trace gas emissions, Global Biogeochem. Cycles, 19, GB3008, doi:10.1029/2004GB002278, 2005.

Tucker, C. J., Pinzón, J. E., Brown, M. E., Slayback, D. A., Pack, E. W., Mahoney, R., Vermote, E. F., and El Saleous, N.: An extended AVHRR 8-km NDVI dataset compatible with MODIS and SPOT vegetation NDVI data, Int. J. of Remote Sens., 26(20), 4485-4498, 2005.

van der Werf, G. R., Randerson, J. T., Collatz, G. J., and Giglio, L.: Carbon emissions from fires in tropical and subtropical ecosystems, Global Change Biol., 9, 547-562, 2003.

van der Werf, G. R., Randerson, J. T., Collatz, G. J., Giglio, L., Kasibhatla, P. S., Arellano, A. F., Olsen, S. C., and Kasischke, E. S.: Continental-scale partitioning of fire emissions during the 1997 to 2001 El Niño/La Niña period, Science, 303, 73-76, 2004.

van Wilgen, B. W. and Scholes, R. J.: The vegetation and fire regimes of southern hemisphere Africa, in: Fire in Southern African Savannas: Ecological and Atmospheric Perspectives, edited by: van Wilgen, B. W., Andreae, M. O., Goldammer, J. G., Lindesay, J., et al., 27-46, Witswatersrand Univ. Press, Johannesburg, South Africa, 1997.

Wooster, M. J.: Small-scale experimental testing of fire radiative energy for quantifying mass combusted in natural vegetation fires, Geophys. Res. Lett., 29, 2027, doi:10.1029/2002GL015487, 2002.

Yurganov, L. N., Duchatelet, P., Dzhola, A. V., Edwards, D. P., Hase, F., Kramer, I., Mahieu, E., Mellqvist, J., Notholt, J., Novelli, P. C., Rockmann, A., Scheel, H. E., Schneider, M., Schulz, A., Strandberg, A., Sussmann, R., Tanimoto, H., Velazco, V., Drummond, J. R., and Gille, J. C.: Increased Northern Hemispheric carbon monoxide burden in the troposphere in 2002 and 2003 detected from the ground and from space, Atmos. Chem. Phys., 5, 563-573, 2005, http://www.atmos-chem-phys.net/5/563/2005/.

Zheng, D. L., Prince, S., and Wright, R.: Terrestrial net primary production estimates for 0.5 degrees grid cells from field observations - a contribution to global biogeochemical modeling, Global Change Biol., 9, 46-64, 2003. 